\title{
Formation of Pyrazol-1,3,4-Thiadiazoles through 1,3-Dipolar Cycloadditions of 3-Thioxo-[1,2,4]-Triazepin-5-one with Nitrilimines: An Experimental and Computational study.
}

\author{
M. Esseffar ${ }^{* a}$, M. El Messaoudi ${ }^{a}$, S. Azzouzi ${ }^{a}$, R. Jalal ${ }^{b}$, J. A. Sáez ${ }^{c}$ L. R. Domingo*c \\ J. Latorre, ${ }^{\mathrm{d}}$ M. Liu-González \\ ${ }^{a}$ Université Cadi ayyad, Faculté des Sciences-Semlalia, Département de Chimie, B.P. 2390, Marrakech, Morocco. \\ ${ }^{\text {b }}$ Université Cadi ayyad, Faculté des Sciences et Techniques, Département des Sciences Chimique, B.P. 549, Marrakesh, \\ Morocco. \\ ${ }^{\mathrm{c}}$ Departamento de Química Orgánica, Universidad de Valencia, Dr. Moliner 50, 46100 Burjassot, Valencia, Spain. \\ ${ }^{\mathrm{d}}$ Instituto de Ciencia de Materiales, Universidad de Valencia, Poligono la coma s/n, 46980 Paterna, Spain. \\ ${ }^{\mathrm{e}}$ S.C.S.I.E (RX) Universidad de Valencia, Dr. Moliner 50,Burjassot 46100, Spain.
}

\begin{abstract}
In this work the results of experimental and computational study of the title compounds and some ancillary compounds are reported. Two bicyclic pyrazol-1,3,4-thiadiazole derivatives were synthesized by reaction between 6-dimethylaminomethylene-3-thioxo-[1,2,4]triazepin-5-one $\mathbf{1}$ and several nitrilimines 2a-f to give corresponding spirocycloadducts 3a-f, which undergo a rapid rearrangement leading to the new bicyclic compounds, 4a-f and 5a-f. These obtained bicyclic products were characterized by ${ }^{1} \mathrm{H}$ and ${ }^{13} \mathrm{C}$ NMR spectroscopy and finally by X-ray crystallography. Theoretical calculations have been carried out using DFT methods to rationalize the formation of the two new bicyclic compounds. Two reaction types are involved in the formation of the compounds $\mathbf{4 a - f}$ and $\mathbf{5 a - f}$. The first one is a 1,3-dipolar cycloaddition reaction between $\mathbf{1}$ acting as dipolarophile and 2a-f as dipoles. The results indicate that the cycloaddition between $\mathbf{1}$ and $\mathbf{2 g}$, as model of 2a-c, takes place via a high asynchronous bond-formation process. The regioselectivity obtained from the calculations is in complete agreement with the formation of the unique spirocycloadducts 3a-f. The second reaction leading to the formation of the final products is a domino process that is initiated by the quick and irreversible cleavage in a catalytic acid environment of triazepenic ring.
\end{abstract}

adedicated to the memory of Tourya El Messaoudi 1975-2003. 


\section{INTRODUCTION}

Triazepine derivatives have attracted a great deal of attention because of their ability to act as anti-convulsant and anti-anxiety. Their oxo and thioxo derivatives have acquired both pharmaceutical and economical relevance. ${ }^{1}$ Triazepines and diazepines have attracted a great attention as starting materiel in the synthesis of fused heterocyclic systems of potential pharmacological activities. ${ }^{2-9}$ Different triazepine derivatives have exhibited significant biological activities. ${ }^{10-13}$ The area of biological interest of this family of compounds have been extended to various diseases such as cancer, ${ }^{7}$ viral infections $(\mathrm{HIV})^{8}$ and cardiovascular disorders. ${ }^{9,10}$ It is known that the pharmacological activity appears to be enhanced when a further heterocyclic ring is linked to the heptatomic nucleus. ${ }^{14,15}$ They are reported as excellent ligands with transition metals inducing a large application in organometallic chemistry. ${ }^{16,17}$

In the context of our current interest in the synthesis of novel heterocyclic compounds, ${ }^{18-22}$ susceptible to have biological activity, we have now studied the 1,3-dipolar cycloaddition (13DC) reaction between 6-dimethylaminomethylene-3-thioxo-[1,2,4]triazepin-5-one 1 and C,N-disubstituted nitrilimines 2a-f (Scheme 1), which were generated in situ from the appropriate precursors and triethylamine. However, we have found that along the purification of reaction mixture by column chromatography, the corresponding spirocycloadducts 3a-f were transformed into the bicyclic compounds 4a-f and 5a-f. Herein, we present the experimental results of the title reaction together with a theoretical study providing an explanation for the formation of the two new bicyclic compounds. Firstly, we describe the synthesis of the novel triazepine 1 and the 13DC reaction with the nitrilimines 2a-f. Then, a theoretical study of the molecular mechanism of the chemical reactions experimentally observed is performed.

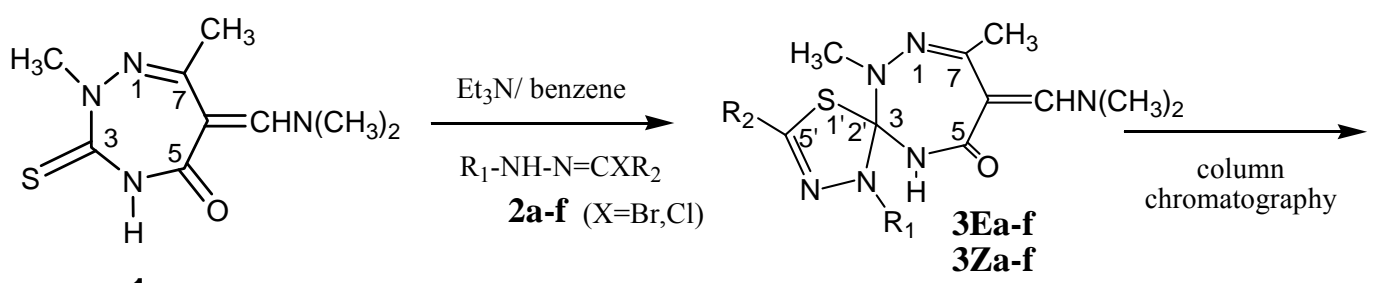

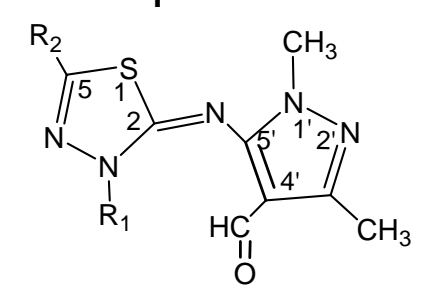

4a-f

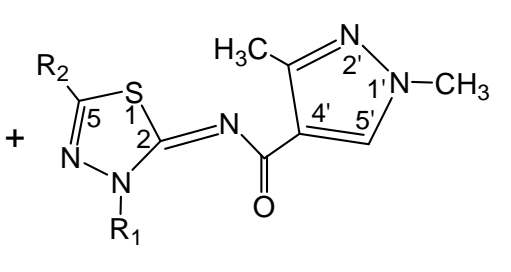

5a-f

Scheme 1 


\section{RESULTS AND DISCUSSION}

\section{Experimental results.}

\subsection{Synthesis of 3-thioxo-[1,2,4]-triazepin-5-one 1}

The 3-thioxo-[1,2,4]-triazepin-5-one 1 was obtained in good yield (70\%) by stirring a mixture of $[1,2,4]$-triazepine 6 and dimethylformamide-dimethylacetal (DMF-DMA) during one hour at $5^{\circ} \mathrm{C}$ (see Scheme 2).

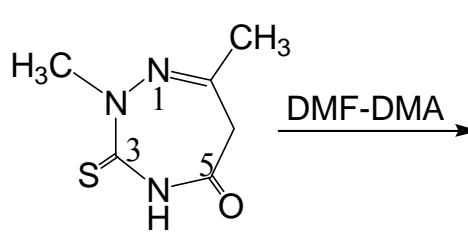

6<smiles>CC1=NN(C)C(=S)NC(=O)C1=CN</smiles>

12<smiles>CC1=NN(C)C([S-])NC(=O)C1=CN(C)C</smiles>

1E

Scheme 2

NMR spectra of the obtained product showed the presence of a mixture of two stereoisomers $1 Z$ and $1 E$. The percentage of these stereoisomers was deduced by ${ }^{1} \mathrm{H}$ NMR spectrum: $34 \%$ and $66 \%$ respectively. The structures of the two stereoisomers were assigned easily by NMR spectra and mass spectrum. In ${ }^{1} \mathrm{H}$ NMR spectrum, the presence of the exocyclic double bond $\mathrm{C}=\mathrm{C}$ is pointed out by two singlets at 7.05 and $7.55 \mathrm{ppm}$ attributables respectively to ethylenic proton $-\mathrm{C}=\mathrm{CH}$ of structures $\mathrm{IZ}$ and $1 E$. This attribution of these values is supported by a simulation of ${ }^{1} \mathrm{H}$ RMN chemical shifts related to ethylenic protons. The higher chemical shift of the ethylenic proton of $1 E$ is due to the proton proximity to the carbonyl group. The ${ }^{13} \mathrm{C}$ NMR spectrum of these stereoisomers is characterized mainly by the absence of resonance signal of methylene group in position 6 and by the presence of signal of carbon $\mathrm{C}_{6}$ at 96.5 for $1 Z$ and $96.1 \mathrm{ppm}$ for $\mathbf{1 E}$. The chemical shifts at 154.5 for $\mathbf{1} E$ and $154.1 \mathrm{ppm}$ for $1 \mathrm{Z}$ attributed to the carbon of exocyclic double bond $(-\mathrm{C}=\underline{\mathrm{CH}})$, permitted to confirm again the presence of this exocyclic double bond. The carbons of thioxo and oxo groups are also clearly identified in this spectrum (177.5 and $168.2 \mathrm{ppm}$ for $1 E$ and 177.2 and $164.9 \mathrm{ppm}$ for $1 Z$ respectively).

1.2. 1,3-Dipolar cycloaddition of 3-thioxo-[1,2,4]-triazepin-5-one 1 with $\mathrm{N}$-aryl-Cethoxycarbonyl-nitrilimines and diarylnitrilimines $2 a-f$.

Nitrilimines 2a-f were generated in situ by treating appropriate ethylhydrazono- $\alpha-$ bromoglyoxylate for 2a-c and $\alpha$-chloroarylidenephenylhydrazones for $\mathbf{2 d - f}$ with triethylamine. After treatment of the 3-thioxo-[1,2,4]triazepin-5-one 1 with nitrilimines 2a-c at room temperature over 72 hours, the spirocycloadducts 3a-c were isolated as a mixture of two stereoisomers $3 E$ and $3 Z$ in a ratio 7:3 (see Scheme 1 and Table 2). However, during the 
separation of the reaction mixture on column chromatography, the cycloaducts were transformed to the bicyclo compounds 4a-c and 5a-c. In the case of the addition of nitrilimines 2d-f, the cycloadducts $\mathbf{3 d - f}$ were not isolated in spite of using all the necessary precautions. The unique isolated products are $\mathbf{4 d - f}$ and $\mathbf{5 d - f}$. When thin-layer chromatography was performed and visualized under UV light, the $\mathbf{3 d - f}$ spot appears as the same time as $\mathbf{4 d - f}$ and 5d-f, but disappears very quickly during the purification. Probably, the attractor effect of CO2Et group presents in 2a-c make the cycloadducts 3a-c relatively more stable than 3d-f. On the other hand, it is known that this type of compounds is described as unstable products. ${ }^{23}$

Table 1. Reaction of 3-thioxo-[1,2,4]-triazepin-5-one 1 with nitrilimines 2a-f.

\begin{tabular}{|c|c|c|c|c|c|c|}
\hline 2 & R1 & R2 & 3 & $(E / Z)$ Percentage & Yield (\%) & Ratio (4:5) \\
\hline $2 a$ & $\mathrm{p}-\mathrm{CH}_{3} \mathrm{C}_{6} \mathrm{H}_{4}$ & $\mathrm{CO}_{2} \mathrm{Et}$ & $3 a$ & $68-32$ & 67 & $55: 45$ \\
\hline $2 \mathbf{b}$ & $\mathrm{p}-\mathrm{ClC}_{6} \mathrm{H}_{4}$ & $\mathrm{CO}_{2} \mathrm{Et}$ & $3 \mathbf{b}$ & $67-33$ & 70 & $54: 46$ \\
\hline 2c & $\mathrm{p}-\mathrm{NO}_{2} \mathrm{C}_{6} \mathrm{H}_{4}$ & $\mathrm{CO}_{2} \mathrm{Et}$ & 3c & $72-28$ & 66 & $53: 47$ \\
\hline 2d & $\mathrm{C}_{6} \mathrm{H}_{5}$ & $\mathrm{p}-\mathrm{CH}_{3} \mathrm{C}_{6} \mathrm{H}_{4}$ & 3d & not isolated & 48 & $54: 46$ \\
\hline $2 e$ & $\mathrm{C}_{6} \mathrm{H}_{5}$ & $\mathrm{p}-\mathrm{ClC}_{6} \mathrm{H}_{4}$ & 3e & not isolated & 48 & $56: 44$ \\
\hline $2 f$ & $\mathrm{C}_{6} \mathrm{H}_{5}$ & $\mathrm{p}-\mathrm{NO}_{2} \mathrm{C}_{6} \mathrm{H}_{4}$ & $3 f$ & not isolated & 42 & $56: 44$ \\
\hline
\end{tabular}

Formation of the spirocycloadducts 3a-c was detected by NMR and mass spectra of their crude reaction. The orientation in the structures 3a-c and the active site of $\mathbf{1}$ were unequivocally determined on the basis of diagnostic ${ }^{1} \mathrm{H}$ and ${ }^{13} \mathrm{C}$ NMR data. This result was confirmed also by X-ray diffraction analysis of $\mathbf{4 d}$ and $5 \mathbf{e}$ compounds (Figure 1). In the proton NMR spectrum of $3 E$ and $3 Z$ cycloadducts, the presence of the exocyclic double bond was justified clearly by two singlets at (7.72-7.75) (3E) and (7.01-7.07) ppm (3Z) characteristics of olefinic protons. The observed shielding of methyl group linked to $\mathrm{N}_{2}$ at (2.58-2.60) (3E) and (2.50-2.58) ppm (3Z) (instead of $3.50 \mathrm{ppm}$ initially) permits to confirm the preferential attack site $(\mathrm{C}=\mathrm{S})$ of the addition of 1 . On the other hand, in ${ }^{13} \mathrm{C} \mathrm{NMR}$ spectrum of the two stereoisomers, the chemical shifts of the carbon atoms at (144.2-145.8) and (118.2-118.9) ppm for $3 E$ and (144.5-146.0) and (117.6-118.4) ppm for $3 Z$ assigned respectively to $=\mathrm{CH}$ and $\mathrm{C}_{6}$ exclude categorically the addition on the exocyclic double bond dipolarophile site. The reactive $\mathrm{C}=\mathrm{S}$ site of the addition was confirmed again in this spectrum by the absence of thioxo group signal. The carbon chemical shifts at (97.2-98.5) and (98.2-98.6) ppm assigned respectively to spiranic carbons of $3 E$ and $3 Z$ are consistent with these structures. The proposed regiochemistry of the addition is in good agreement with that observed for other related systems. ${ }^{24}$ The nitrogen atom of the dipole is linked to the 
carbon atom of dipolarophile site $\mathrm{C}=\mathrm{S}$. No condensation products of the dipole on the dipolarophile sites $(\mathrm{C}=\mathrm{C}, \mathrm{C}=\mathrm{N}$ and $\mathrm{C}=\mathrm{O})$ has been observed. It is to note that while the extraction was made using a more polar solvent, as dichloromethane, the cycloadduct 3 was not isolated evolving directly the conversion to the compounds $\mathbf{4}$ and $\mathbf{5}$.

For the isolated 1,2-pyrazol-1,3,4-thiadiazole 4d and 5e, the X-ray diffraction and spectral data are in accordance with the proposed structures (Scheme 1). Thus, the examination of NMR spectra and mass spectrum shows that these products are formed by monocycloaddition of nitrilimine on the double bond $\mathrm{C}=\mathrm{S}$. Then the corresponding cycloadducts are transformed into 4a-f and 5a-f compounds. In ${ }^{1} \mathrm{H}$ NMR spectra of 4a-f compounds, we noted in particular the chemical shift of aldehyde proton at about (9.74-9.83) ppm. The $=\mathrm{C}-\mathrm{CH}_{3}$ and $\mathrm{N}-\mathrm{C}_{3}$ protons resonate as singlet at $(2.38-2.56)$ and $(3.50-3.61) \mathrm{ppm}$ respectively. Methyl and methylene of $\mathrm{CO}_{2}$ Et group show triplet and quartet at about (1.321.43) and (4.37-4.49) ppm respectively. In ${ }^{13} \mathrm{C}$ NMR spectra of 4a-f the aldehyde carbonyl is confirmed again by the presence of the pick at (182.4-183.3) ppm. The signals of the carbon atoms $\mathrm{C}_{5}$ (151.4-153.0) ppm, $\mathrm{C}_{4}$, (108.4-109.1) ppm, $\mathrm{C}_{5}$, (149.8-151.3) ppm and $\mathrm{C}_{2}$ (160.5162.0) ppm confirm also the proposed structures. For compounds 5a-f, the presence of the olefinic protons is pointed out by a singlet at about (7.82-7.89) ppm. On the other hand, the ${ }^{13} \mathrm{C}$ NMR spectra reveal mainly the signals at (118.3-119.1), (135.1-136.7), (147.9-151.8), (151.9-156.3) and (163.4-164.9) ppm, attributed respectively to carbons $\mathrm{C}_{4}, \mathrm{C}_{5}, \mathrm{C}_{3}, \mathrm{C}_{5}, \mathrm{C}_{2}$.

To sum up, the 13DC reactions of 3-thioxo-[1,2,4]-triazepin-5-one $\mathbf{1}$ with the nitrilimines 2a-f are completely chemo and regioselective. In all cases the carbon atom of dipoles is linked to the sulphur atom of dipolarophile $\mathrm{C}=\mathrm{S}$ site of $\mathbf{1}$. No addition of dipoles were observed on the $\mathrm{C}=\mathrm{N}$ and $\mathrm{C}=\mathrm{O}$ double bonds, and the exocyclic $\mathrm{C}=\mathrm{C}$ double bond. However, along the purification of reaction mixture, the corresponding spirocycloadducts 3a-f were quickly transformed into the bicycle compounds $\mathbf{4 a - f}$ and $\mathbf{5 a - f .}$

\subsection{X-ray crystallography analysis.}

The molecular structures of $\mathbf{4 d}$ and $5 \mathbf{e}\left(\mathrm{C}_{21} \mathrm{H}_{18} \mathrm{~N}_{5} \mathrm{OS}\right.$, triclinic and $\mathrm{C}_{21} \mathrm{H}_{16} \mathrm{ClN}_{5} \mathrm{OS}$, monoclinic) determined X-ray crystallography in this work are shown in Fig.1. The structures of $\mathbf{4 d}$ and $5 \mathbf{e}$ were obtained by slowly evaporating a benzene solution. Analysis of these X-ray structures allows to obtain some interesting features for the conversion of the spirocycloadducts 3a-f in the compounds 4a-f and 5a-f: i) the $[1,2,4]$ triazepine ring is not present in these compounds, ii) the five-membered ring formed along the 13DC reaction remains in these structures, iii) the enamine substituent present in triazepine $\mathbf{1}$ is hydrolysed along these processes; iv) two new five-membered heterocycle compounds are formed along 
the reaction; and v) these heterocycle compounds contain an $\alpha, \beta$-unsaturated carbonyl group: one aldehyde on $\mathbf{4 d}$ and one ketone on $\mathbf{5 e .}$

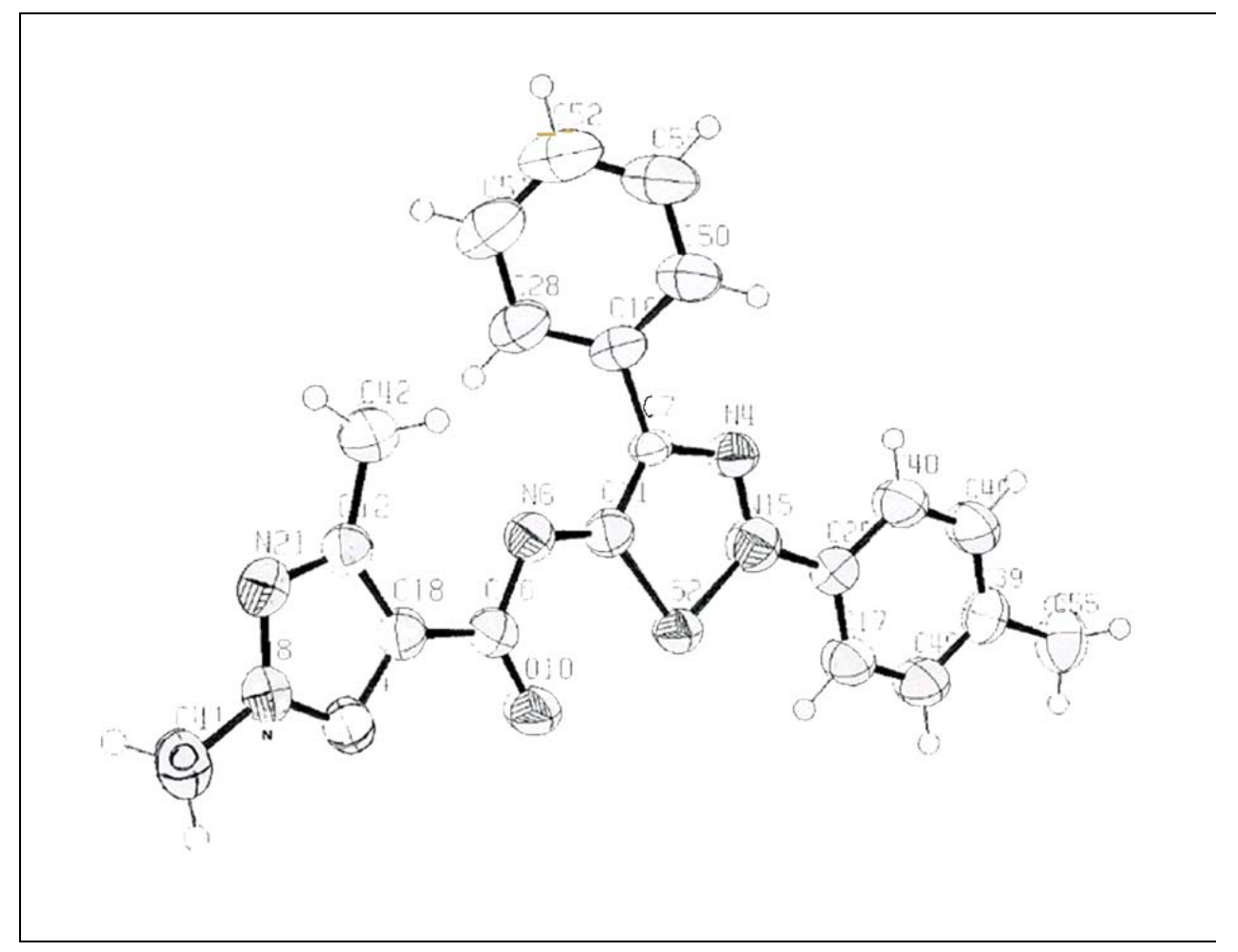

4d

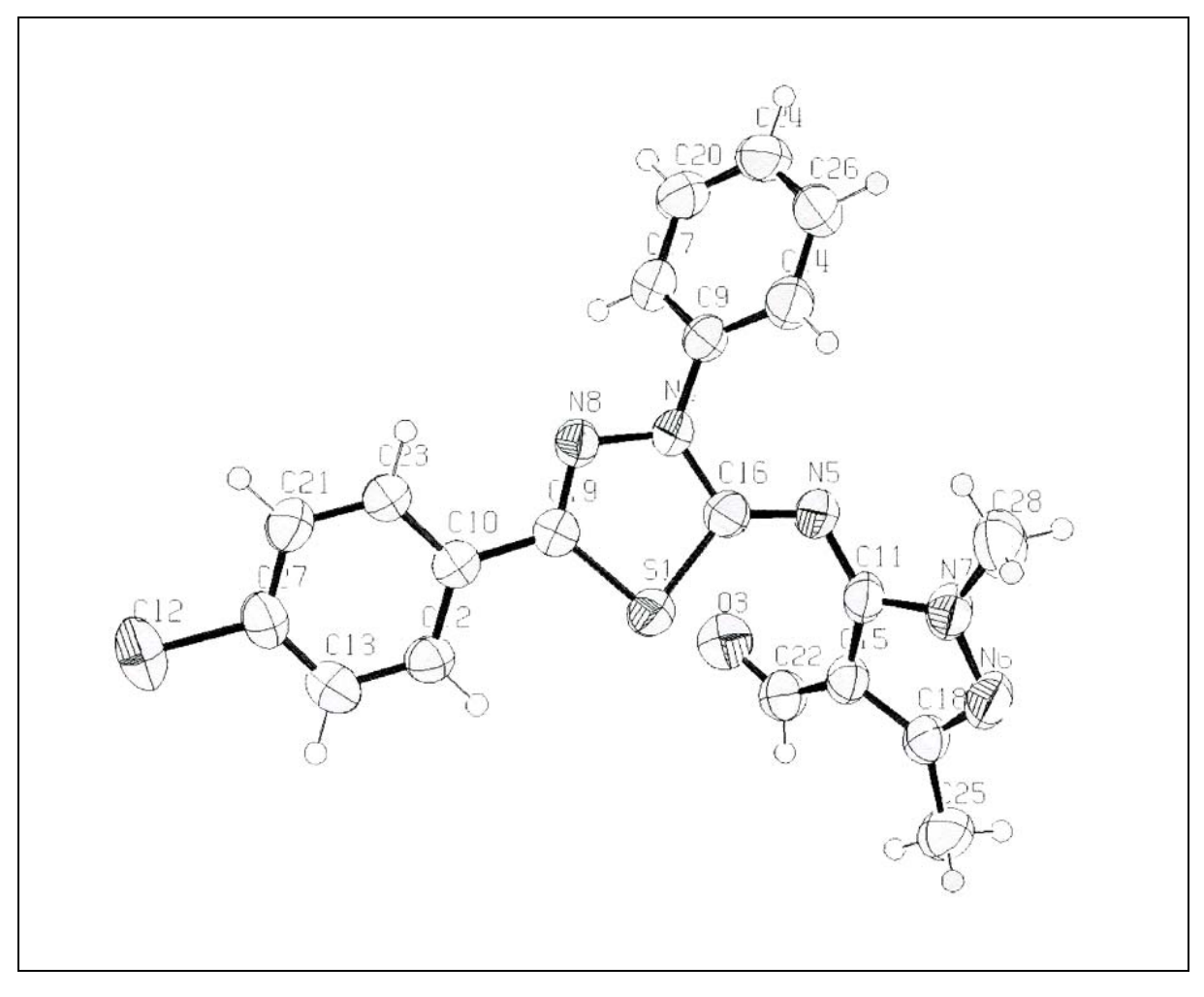

$5 e$

Figure 1. The molecular structure of compound 4d and 5e (ORTEP: XTAL 3.6) with the numbering scheme. Displacement ellipsoids are drawn at 30\% probability. 


\section{Theoretical results}

2.1. Study of the 1,3-dipolar cycloaddition reaction between 3-thioxo-[1,2,4]-triazepin-5-one $\mathbf{1}$ and C-methoxycarbonyl-nitrilimine $\mathbf{2 g}$.

Firstly, the 13DC reaction between 3-thioxo-[1,2,4]-triazepin-5-one $\mathbf{1}$ and the Cmethoxycarbonyl-nitrilimine $\mathbf{2 g}$, as a model of the nitrilimines a-c, was studied (see Scheme 3). As it has been indicated in the experimental part, in spite of the presence of four dipolarophile sites in $\mathbf{1}$, these reactions take place with a total chemoselectivity; only the $\mathrm{C}=\mathrm{S}$ double bond participates as dipolarophile in these $13 \mathrm{DC}$ reactions. ${ }^{22}$ According to the experimental result, we decided to perform the computational study of the addition of the nitrilimine $2 \mathrm{~g}$ to the $\mathrm{C}=\mathrm{S}$ double bond of $\mathbf{1}$. For this $13 \mathrm{DC}$ reaction, the two regioisomeric channels associated to the addition of $\mathbf{2 g}$ to the unsymmetric $\mathrm{C}=\mathrm{S}$ double bond of $\mathbf{1}$ were studied. In addition, the $E / Z$ configurational dispositions of the exocyclic $\mathrm{C}=\mathrm{C}$ double bond present on 1 were also considered. An analysis of the stationary points found along the four reaction paths points out that these 13DC reactions have one-step mechanism. Thus, four TSs, TS1-E, TS1-Z, TS2-E, TS2-Z, and four [3+2] spirocycloadducts 3g- $E$, 3g- $Z$, 7g- $E$ and $7 \mathrm{~g}-Z$ were located and characterized (see Scheme 3). The B3LYP/6-31G* total and relative energies are collected in Table 2.

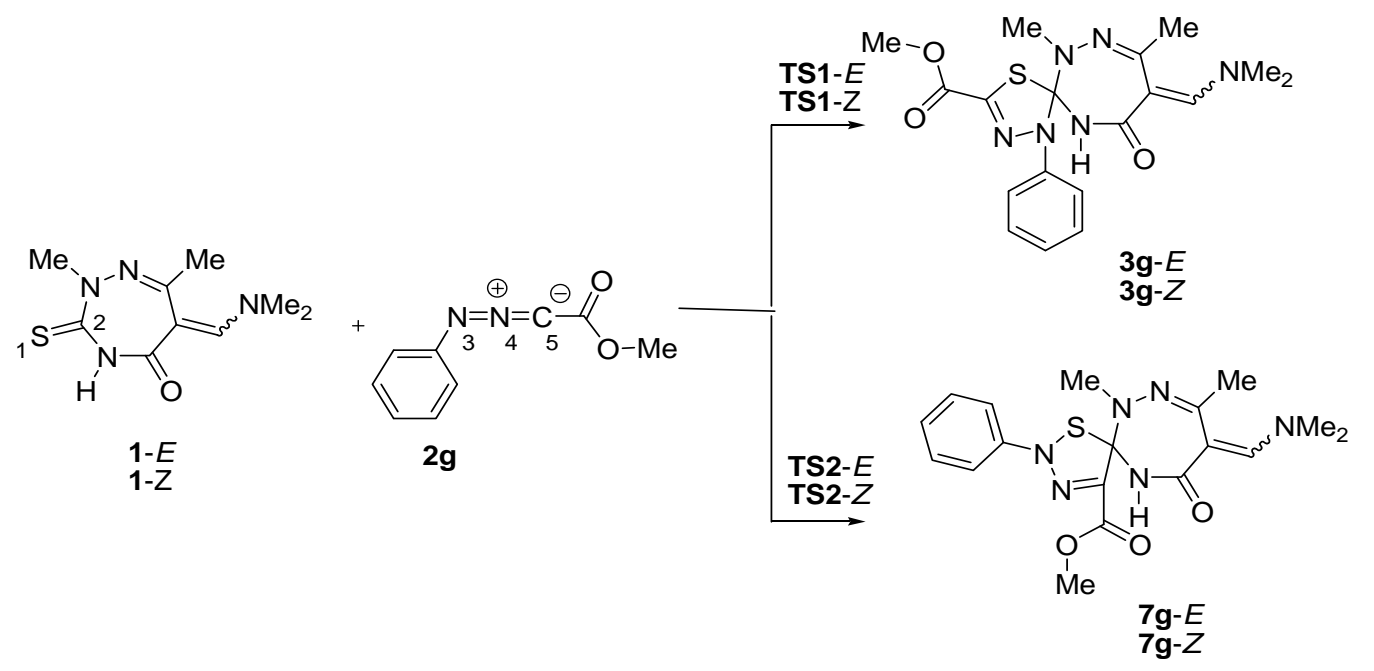

Scheme 3

The activation energies associated to the formation of the spirocycloadducts $3 \mathbf{g}-E$ and 3g-Z, via TS1-E and TS1-Z, present very low values: 3.5 and $3.7 \mathrm{kcal} / \mathrm{mol}$, respectively. The $E / Z$ configuration of the exocyclic $\mathrm{C}=\mathrm{C}$ double bond has not any appreciable incidence on the activation energies. These cycloadditions are strongly exothermic: $-23.6(3 \mathbf{g}-E)$ and $23.2(3 \mathrm{~g}-Z) \mathrm{kcal} / \mathrm{mol}$. On the other hand, formation of the regiosiomeric cycloadducts $7 \mathbf{g}-E$ and $7 \mathbf{g}-Z$ present very large activation energies: 21.0 (TS2-E) and 21.7 (TS2-Z) kcal/mol. 
These energy results are in agreement with the complete regioselectivity experimentally observed. Formation of the regioisomeric cycloadducts are also less exothermic; -12.9 (7gE) and $-15.1(7 \mathrm{~g}-Z) \mathrm{kcal} / \mathrm{mol}$.

Table 2. Total $(\mathrm{E}, \mathrm{au})$ and relative $(\Delta \mathrm{E}, \mathrm{kcal} / \mathrm{mol})$ energies, in gas-phase and benzene, and total $(\mathrm{G}, \mathrm{au})$ and relative $(\Delta \mathrm{G}, \mathrm{kcal} / \mathrm{mol})$ free energies in benzene for stationary points involved in the $13 \mathrm{DC}$ reactions of $\mathbf{1}-E$ and $\mathbf{1}-Z$ with $\mathbf{2 g}$.

\begin{tabular}{lrrrrrr}
\hline & \multicolumn{2}{c}{ gas-phase } & \multicolumn{5}{c}{ benzene } \\
\hline 1-E & $\mathrm{E}$ & $\Delta \mathrm{E}$ & $\mathrm{E}$ & $\Delta \mathrm{E}$ & $\mathrm{G}$ & \multicolumn{1}{c}{$\mathrm{G}$} \\
$\mathbf{1 - Z}$ & -1043.772302 & & -1043.781561 & & -1043.598519 & \\
$\mathbf{2 g}$ & -1043.772618 & & -1043.781063 & & -1043.597913 & \\
TS1-E & -607.634412 & & -607.638885 & & -607.528673 & \\
TS1-Z & -1651.401206 & 3.5 & -1651.413185 & 4.6 & -1651.100245 & 16.9 \\
3g- $E$ & -1651.401206 & 3.7 & -1651.412283 & 4.8 & -1651.100349 & 16.8 \\
3g-Z & -1651.444258 & -23.6 & -1651.454657 & -21.5 & -1651.134958 & -4.9 \\
TS2-E & -1651.443973 & -23.2 & -1651.453334 & -20.9 & -1651.130806 & -2.3 \\
TS2-Z & -1651.373260 & 1.0 & -1651.383731 & 23.0 & -1651.068242 & 37.0 \\
7g- $E$ & -1651.372481 & 21.7 & -1651.382129 & 23.7 & -1651.066401 & 37.8 \\
7g- $Z$ & -1651.427249 & -12.9 & -1651.435868 & -9.7 & -1651.118121 & 5.3 \\
\hline & -1651.431159 & -15.1 & -1651.438630 & -11.7 & -1651.119144 & 4.7 \\
\hline
\end{tabular}

The geometries of the TSs involved in these 13DC reactions are depicted in Figure 2. At the more favourable regioisomeric TSs, TS1-E and TS1-Z, the length of the S1-C5 forming bond is 2.408 and $2.407 \AA$, while the distance between the $\mathrm{C} 2$ and the N3 atoms is 3.288 and $3.321 \AA$ respectively. These values point out to very asynchronous bondformation processes in which the S1-C5 bond-formation is anticipated to the $\mathrm{C} 2-\mathrm{N} 3$ one. At the more unfavourable regioisomeric TSs, TS2-E and TS2-Z, the length of the C2-C5 forming bond is 2.096 and $2.092 \AA$, while the length of the S1-N3 bond is 2.482 and 2.482 Á, respectively. These TSs are more advanced and more synchronous. 


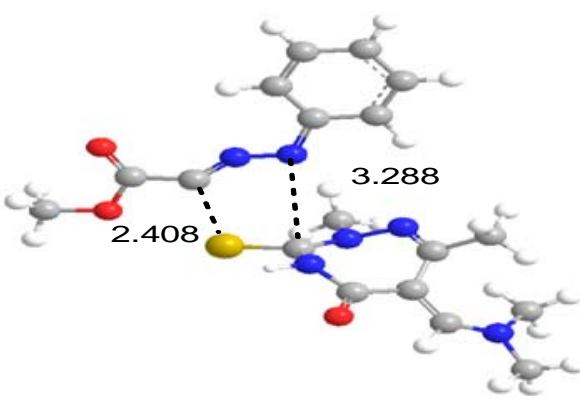

TS1-E

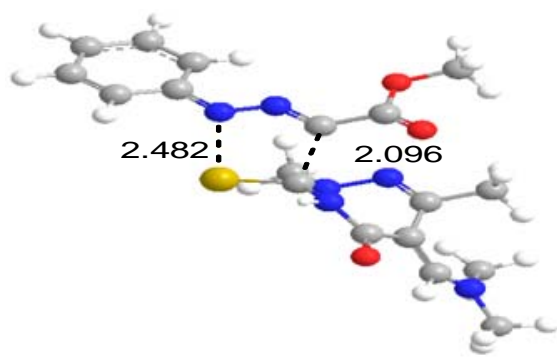

TS2-E

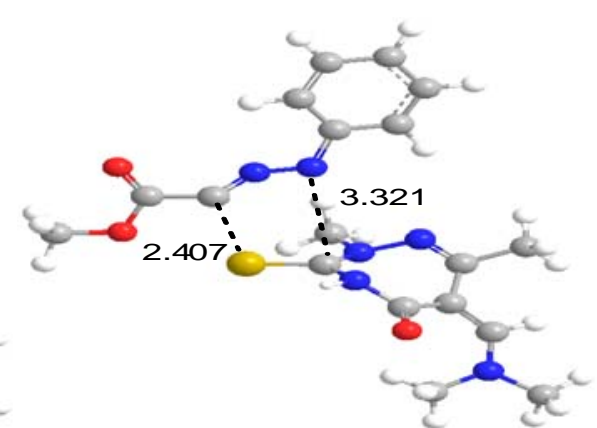

TS1- $Z$

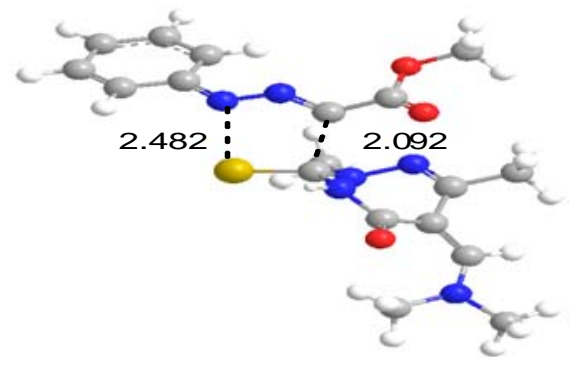

TS2- $Z$

Figure 2. Transition structures for the 13DC reactions of 3-thioxo-[1,2,4]-triazepin-5-one 1$E$ and $1-Z$ with 2 g. The values of the bond lengths are given in $\AA$.

Analysis of the bond orders (BO) and the charge transfer (CT) at the TSs allows to establish the electronic nature of these 13DC reactions. At the more favourable regioisomeric TSs, TS1-E and TS1-Z, the BO values of the S1-C5 forming bond are 0.33 and 0.34, while the BO values between the $\mathrm{C} 2$ and the $\mathrm{N} 3$ atoms are 0.03 . These $\mathrm{BO}$ values indicate that only the S1-C5 bond is being formed at these asynchronous TSs. On the other hand, at the more unfavourable regioisomeric TSs, TS2-E and TS2-Z, the BO values of the C2-C5 and S1-N3 forming bonds are 0.43 and 0.30, respectively. These values point to concerted bond formation process where the C2-C5 bond formation is more advanced than the S1-N3 one.

The CT at these cycloadditions was analyzed sharing the natural charges between the dipole and the dipolarophile fragments. At the more favourable regioisomeric TSs, the CT that fluxes from the 3-thioxo-[1,2,4]-triazepin-5-one $\mathbf{1}$ to the nitrilimine $\mathbf{2 g}$ is $0.26 \mathrm{e}$ at both $E / Z$ TSs. This large value indicates that these TSs have some zwitterionic character. On the other hand, at the more unfavourable regioisomeric TSs the CT is negligible, $0.05 \mathrm{e}$, and it takes place in the opposite direction. This analysis indicates that the two regioisomeric cycloadditions are associated to unlike chemical processes. While the TSs associated to the 
most favourable regioisomeric channels can be associated to two-center interactions between the most nucleophilic site of the 3-thioxo-[1,2,4]-triazepin-5-one 1, the sulphur S1 atom, and the most electrophilic site of nitrilimine $\mathbf{2 g}$, the carbon C5 atom, the TSs associated to the more unfavourable regioisomeric channels can be related to four-center interactions characteristic of concerted cycloaddition processes. The flux of the CT found at the more favourable TSs is in agreement with the large electrophilic character of the nitrilimine $\mathbf{2 g}, \omega$ $=1.75 \mathrm{eV}$, than that of 3-thioxo-[1,2,4]-triazepin-5-one 1-E, $\omega=1.30 \mathrm{eV} .^{25}$

As these cycloadditions have some polar character, and solvent can modify the energies, effect of benzene was considered. In benzene, all species are stabilized between 3 and $8 \mathrm{kcal} / \mathrm{mol}$. The more stabilized species are TS1-E and TS1- $Z$ due to their polar character, 7.5 and $7.0 \mathrm{kcal} / \mathrm{mol}$, respectively. However, the separated reagents become slightly more solvated. As a consequence, the activation energies increase in $1.1 \mathrm{kcal} / \mathrm{mol}$. Solvent effects have not any incidence on the regioselectivity of the studied reaction.

Finally, the inclusion of the thermal corrections and entropies to the total energies in benzene raises the free energies between 12 and $19 \mathrm{kcal} / \mathrm{mol}$ due to the bimolecular nature of these cycloadditions (see Table 2). The free activation energies associated TS1-E and TS1-Z are 16.9 and $16.8 \mathrm{kcal} / \mathrm{mol}$. The regioisomeric TSs remains $c a .20 \mathrm{kcal} / \mathrm{mol}$ above the more favourable TSs. Finally, formation of the spirocycloadducts $3 g-E$ and $3 g-Z$ are slightly exergonic, -4.9 and $-2.3 \mathrm{kcal} / \mathrm{mol}$, respectively.

\subsection{Study of conversion of spirocycloadducts 3a-f into bicycloderivatives $\mathbf{4 a}-\mathbf{f}$ and $\mathbf{5 a}-\mathbf{f}$.}

The spirocycloadducts 3a-f are very unstable, and they are converted quickly into the two bicyclo compounds 4a-f and 5a-f (see Scheme 1). Therefore, we have considered to study these conversions. Based on these observations obtained from the $\mathrm{X}$-ray crystallography analysis of the compounds of $\mathbf{4 d}$ and $5 \mathbf{e}$ (see section 1-3) we have proposed a mechanism for the conversions that considers all structural changes (see Scheme 4). In a first step, the triazepine ring is opened by a N1-C2 breaking bond process to give the intermediate $\mathbf{8}$. Then, the enamine substituent present in $\mathbf{8}$ is hydrolysed to the corresponding aldehyde, yielding the dicarbonylic intermediate 9. Note that the ring cleavage and the enamine hydrolysis are independent. However, due to the large instability of these spirocompounds in an acid medium (see later) we assume that the ring cleavage takes place firstly. After the enamine hydrolysis, the two carbonyl groups on $\mathbf{9}$ can experiment an intramolecular condensation reaction with the terminal amine N1 atom. Formation of the new N-C bond via the intramolecular nucleophilic attack of the amine to each carbonyl 
group present on 9 allows the formation of the two new five-membered heterocycles. Finally, a water elimination process on the bicyclic intermediates $\mathbf{1 0}$ and $\mathbf{1 1}$ allows the formation of $\mathbf{4 g}$ and $5 g$.

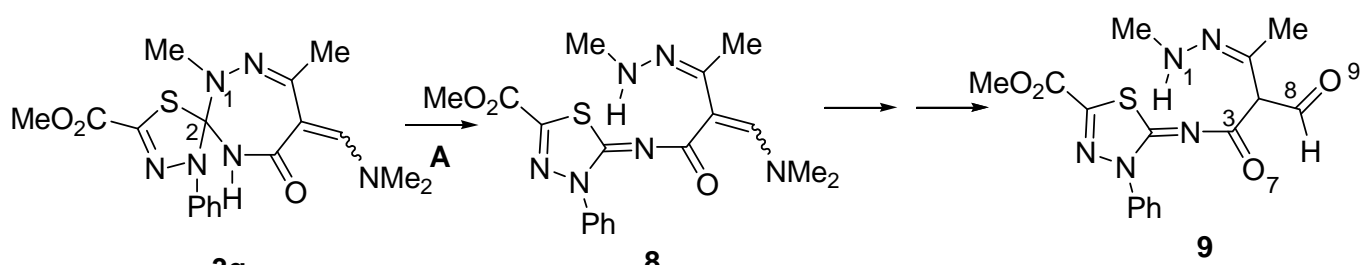

$3 g$

8

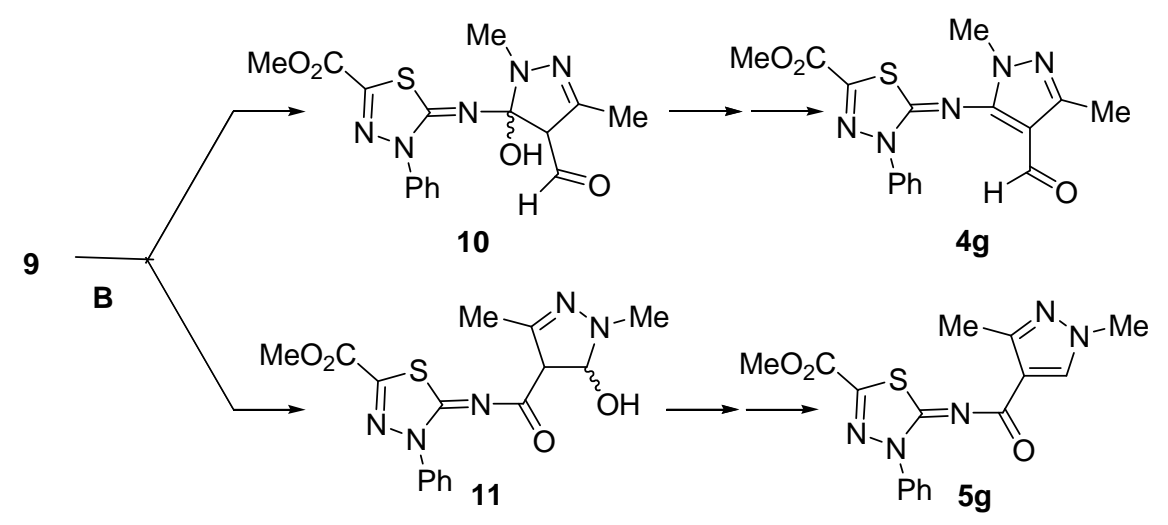

Scheme 4

Due to the complexity of this mechanism, we decided to study the two more significant elementary steps (see A and $\mathbf{B}$ in Scheme 4). They include the ring cleavage of the triazepine ring, step A, and the ring closure of the dicarbonylic intermediate $\mathbf{9}$ with formation of the new bicyclic intermediates $\mathbf{1 0}$ and 11, step B. Note that hydrolysis of enamines and condensation reactions of carbonyl compounds with amines are common reactions in the chemistry of the carbonyl group. In addition, due to that the thiazole ring does not participate in the domino reaction, the methoxycarbonyl and phenyl groups present in the thiazole ring have been replaced by two hydrogen atoms in order to work with a more reduced model.

All steps of the proposed mechanism need an acid catalysis in order to facilitate the breaking- and forming-bond processes associated to each elementary process (see Scheme 5). After the protonation of the N1 nitrogen atom of the triazepinone ring of the spirocycloadduct 3 , the activation energy associated to the N1-C2 breaking-bond of the intermediate IN1 via TS3, is only of $2.6 \mathrm{kcal} / \mathrm{mol}$. This ring cleavage process is very exothermic, $-23.9 \mathrm{kcal} / \mathrm{mol}$. These energy results indicate that in acid environment the spirocycloadducts 3a-f are kinetically and thermodynamically very unstable, yielding 
irreversibly the open intermediates as $\mathbf{8}$ (see Scheme 4). Note that the N1 nitrogen atom of these spirocycloadducts corresponds to the most basic center of these molecules.

a) step of ring-cleavage

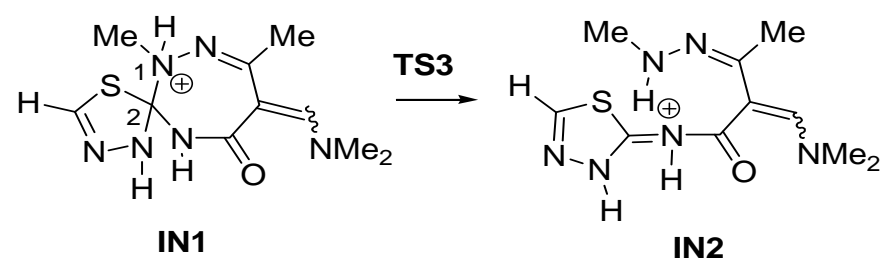

b) step of ring-formation

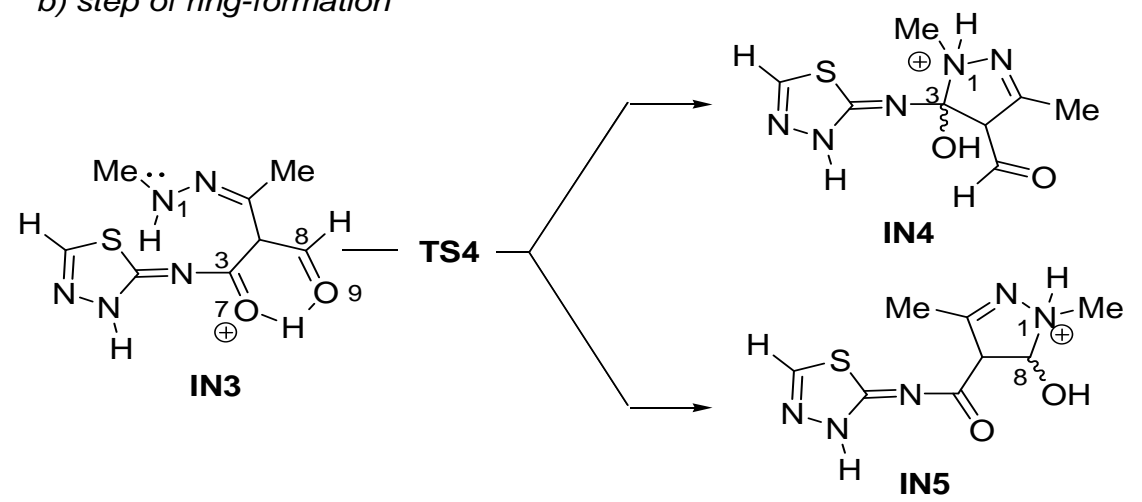

Scheme 5

For the ring-closure step with formation of the five-membered heterocycles present in $4 \mathbf{g}$ and $5 \mathbf{g}$, we found a unique TS4 followed by a downhill intrinsic reaction coordinate until the path bifurcates into two equivalent downhill pathways allowing the formation of the intermediate IN4, result of the nucleophilic attack of the amine N1 nitrogen atom to the ketone $\mathrm{C} 3$ carbon atom, and the intermediate IN5, result of the attack of this nitrogen atom to the aldehyde $\mathrm{C} 7$ carbon atom. This TS is located only $1.1 \mathrm{kcal} / \mathrm{mol}$ above the intermediate IN3. Formation of the intermediates IN4 and IN5 is exothermic in -1.8 and $-24.7 \mathrm{kcal} / \mathrm{mol}$, respectively. The low exothermic character of IN4 can be related to the loss of the conjugation associated to the nucleophilic attack to the ketone group. Spite of the low exothermic character of formation of the intermediate IN4, the quick exchange of the N1 proton by an acid/base process can turn irreversible this step after water elimination. Full optimisation of the stationary points associated to the paths $\mathbf{A}$ and $\mathbf{B}$ at the B3LYP/6-31+G* does not produce appreciable changes (see Table 3). Only the relative energy of TS4 increases to $10.5 \mathrm{kcal} / \mathrm{mol}$. 
Table 3. Total (E, au) and relative $(\Delta \mathrm{E}, \mathrm{kcal} / \mathrm{mol})$ energies, in gas-phase and dichloromethane, and total $(\mathrm{G}, \mathrm{au})$ and relative $(\Delta \mathrm{G}, \mathrm{kcal} / \mathrm{mol})$ free energies in dichloromethane, for the more relevant stationary points corresponding to the reaction model for transformation of spirocycloadduct $\mathbf{3 g}$ to $\mathbf{4 g}$ and $\mathbf{5 g}$ products.

\begin{tabular}{|c|c|c|c|c|c|c|c|c|}
\hline & B3LYP/6-31G & & B3LYP/6-31+ & & & $3 \mathrm{LYP} / 6$ & $\mathrm{G}^{*}$ & \\
\hline & & gas-ph & & & & chlorom & ane & \\
\hline & $\mathrm{E}$ & $\Delta \mathrm{E}$ & $\mathrm{E}$ & $\Delta \mathrm{E}$ & $\bar{E}$ & $\Delta \mathrm{E}$ & G & $\Delta \mathrm{G}$ \\
\hline IN1 & -1192.905939 & & -1192.928240 & & -1192.977586 & & -1192.75108 & \\
\hline TS3 & -1192.901739 & 2.6 & -1192.924370 & 2.4 & -1192.974637 & 1.9 & -1192.74961 & 0.9 \\
\hline IN2 & -1192.944099 & -23.9 & -1192.965038 & -23.1 & -1193.011543 & -21.3 & -1192.78486 & -21.2 \\
\hline IN3 & -1134.158984 & & -1134.180397 & & -1134.236299 & & -1134.07706 & \\
\hline TS4 & -1134.157262 & 1.1 & -1134.163718 & 10.5 & -1134.234001 & 1.4 & -1134.07179 & 3.3 \\
\hline IN4 & -1134.161908 & -1.8 & -1134.183691 & -2.1 & -1134.238627 & -1.5 & -1134.07442 & 1.7 \\
\hline IN5 & -1134.198415 & -24.7 & -1134.220647 & -25.3 & -1134.274285 & -23.8 & -1134.10736 & -19.0 \\
\hline
\end{tabular}

The geometries of TS3 and TS4 are given in Figure 3. At TS3, the length of the N1-C2 breaking bond is $2.138 \AA$, while the BO value is 0.31 . At TS4, the distance between the amine N1 nitrogen atom and the aldehyde carbonyl C7 carbon atom and the ketone carbonyl C3 carbon atom is 2.909 and $2.787 \AA$, respectively. These large distances point out the early character of this TS.

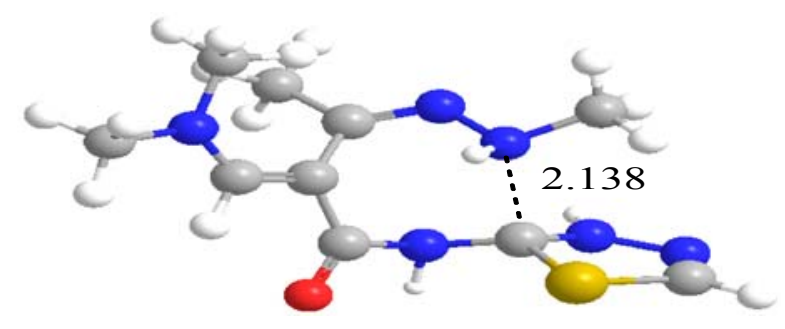

TS3

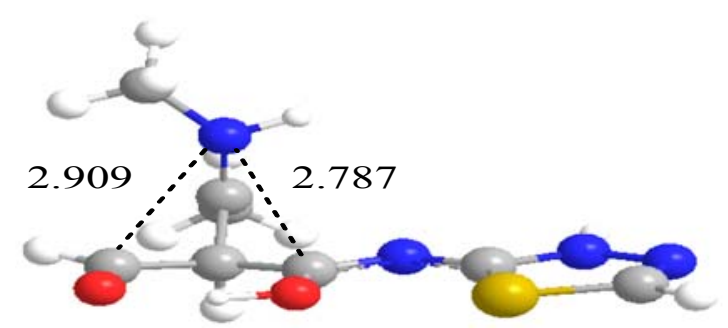


Figure 3. Transition structures involved in the reaction model for the transformation of spirocycloadduct $\mathbf{3 g}$ to $\mathbf{4} \mathbf{g}$ and $\mathbf{5 g}$ products.

At the intermediate IN3 the protonation takes place at the most basic ketone $\mathrm{O} 7$ oxygen atom, but the proton forms also a strong hydrogen bond with the aldehyde O9 oxygen atom, with a bond length of $1.615 \AA$ A. This behaviour remains also at TS4. The IRC from TS4 to IN4 shows that along the nucleophilic attack of the amine N1 nitrogen atom to the aldehyde $\mathrm{C} 7$ carbon atom, the proton moves from the ketone $\mathrm{O} 7$ oxygen atom to the aldehyde $\mathrm{O} 9$ oxygen atom, thus stabilising the negative charge that develops at the aldehyde O9 oxygen atom along the nucleophilic attack to the C8 carbon atom. The same mechanism, related to the synthesis of pyrazoles reaction of hydrazines with beta-dicarbonyl compounds, has been studied by Elguero and coworkers. ${ }^{26}$

Dichloromethane stabilises all structures between $42-49 \mathrm{kcal} / \mathrm{mol}$, as a consequence of the cationic character of this species. However, the inclusion of solvent effect does not modify the gas-phase relative energies. Finally, the inclusion of the thermal corrections and entropies to the total energies in dichloromethane causes minor changes on the relative free energies associated to this domino process due to the intramolecular nature of the two elementary steps. The activation free energies for the two elementary steps present very low values, $0.9 \mathrm{kcal} / \mathrm{mol}$ (TS3) and $3.3 \mathrm{kcal} / \mathrm{mol}$ (TS4) (see Table 3). These values support the feasibility of these steps. On the other hand, formation of the intermediate IN2 is a strongly exergonic process, $-21.2 \mathrm{kcal} / \mathrm{mol}$. Therefore, in an acid medium, the spirocycloadducts as 3g are kinetically and thermodynamically very unstable in clear agreement with the experimental outcome.

In conclusion, both energy results and geometries associated to the $\mathbf{A}$ and $\mathbf{B}$ elementary steps studied in Scheme 5 support the mechanism proposed in Scheme 4 for the transformation of the spirocycloadduct $\mathbf{3 g}$ into the bicyclo compounds $\mathbf{4 g}$ and $\mathbf{5 g}$. Note that for the other non-studied elementary steps of Scheme 4, it is assumed that they take place easily. 


\section{CONCLUSION}

New bicyclic pyrazol-1,3,4-thiadiazole derivatives 4a-f and 5a-f have been synthesized by reaction between the 3-thioxo-[1,2,4]-triazepin-5-one $\mathbf{1}$ and several nitrilimines 2a-f. The studied reactions take place through two reaction types: a 13DC reaction between $\mathbf{1}$ and 2a-f, and a domino reaction allowing the conversion of the corresponding spirocycloadducts 3a-f into the final bicyclic compounds 4a-f and 5a-f, which were characterized by NMR and Xray analyses. The mechanism of the two reaction types have been theoretically studied using DFT calculations at the B3LYP/6-31G(d) level. The spirocycloaduct $3 g$ is obtained through a 13DC reaction via a high asynchronous mechanism with a very low activation energy. The computational results support the total regioselectivity experimentally observed. For the conversion of the spirocycloadducts 3a-f into the two biciclyc compounds 4a-f and 5a-f, a domino reaction that comprises the cleavage of the triazepin ring, hydrolysis of the enamine substituent, and two intramolecular condensation reactions to form the two new fivemembered heterocycles has been proposed. The elementary steps responsible for the N2-C3 cleavage of the triazepin ring and the intramolecular nucleophilic addition reaction to the carbonyl groups to yield the thiazolo and diazolo rings have been studied. The energy results obtained for these elementary steps support the suitability of the proposed mechanism, allowing to explain formation of the two bicyclic pyrazol-1,3,4-thiadiazole derivatives. 


\section{COMPUTATIONAL METHODS}

Quantum chemical calculations were performed with the use of the Gaussian 03 set of programs. ${ }^{27}$ All structures were fully optimized with the density functional theory (DFT) using Becke's three parameter hybrid method ${ }^{28}$ and correlation functional of Lee-Yang-Parr (B3LYP) ${ }^{29}$ in conjunction with the $6-31 \mathrm{G}^{*}$ and $6-31+\mathrm{G}^{* 30}$ basis sets. The stationary points were characterized by harmonic vibrational frequency analysis in order to verify that minima and transition structures have zero and one imaginary frequency, respectively. Starting from a transition structures, the intrinsic reaction coordinate $(\text { IRC })^{31}$ pathway has also been constructed in order to verify further its identity and also map out a minimum energy reaction pathway. Net atomic charges of the stationary points were obtained by using the natural bond orbital (NBO) approach. ${ }^{32}$ The solvent effects have been considered by B3LYP/6-31G* single point calculations over the gas phase optimized structures using a self-consistent reaction field ${ }^{33}$ (SCRF) based on the PCM method of the Tomasi's group. ${ }^{34}$ Since these reactions are carried out in benzene and dichloromethane, we have selected its dielectric constants at $298.0 \mathrm{~K}$. The values of the free energies in benzene and dichloromethane were calculated with the standard statistical thermodynamics at $298.15 \mathrm{~K}$ and $1 \mathrm{~atm}^{30}$ Thermodynamic calculations were scaled by a factor of 0.96 .

\section{EXPERIMENTAL SECTION}

Melting points were taken on a Buchi 510 apparatus and were uncorrected. The $1 \mathrm{H}$ NMR spectra were recorded with the following instruments: Bruker WP $400 \mathrm{CW}$ and AC 250 . TMS was used as an internal reference. The 13C NMR spectra were measured on a Varian FT $80(20.0 \mathrm{MHz})$. Mass spectra were recorded with a JEOL JMS DX 300. Column chromatography was carried out using E-Merck silica gel 60F254. Reagents and solvents were purified in the usual Way. The data collections of X-ray structures were performed at $293^{\circ} \mathrm{K}$ on a Nonius Kappa-CCD single crystal diffractometer, using Mo Kạradiation .$(\lambda=0.7173 \AA)$. Crystal-detector distance was fixed at $35 \mathrm{~mm}$, and a total of 220/ 325 images were collected using the oscillation method, with scan angle per frame $2^{\circ}$ oscillation and $20 \mathrm{~s}$. exposure time per image. Data collection strategy was calculated with the program Collect. ${ }^{35}$ Data reduction and cell refinements were performed with the programs HKL Denzo and Scalepack. ${ }^{36}$ The crystal structure was solved by direct Methods, using the program SIR-97. ${ }^{37}$ Anisotropic least-squares refinement was carried out with SHELXL-97. ${ }^{38}$ All non hydrogen 
atoms were anisotropically refined. Some Hydrogen atoms were located in a difference Fourier maps and the remaining ones located geometrically. Geometrical calculations were made with PARST. ${ }^{39}$ The crystallographic plots were made with Mercury. ${ }^{40}$

\section{Synthesis of $[1,2,4]$ triazepine 1}

A solution of 3-thioxo[1,2,4]triazepin-5-one 6 (5.8mmol.) and dimethyl formamidedimethyl acetal (DMF-DMA) $(20 \mathrm{ml})$ was stirred for $1 \mathrm{~h}$ at $5^{\circ} \mathrm{C}$. The precipitated solid was filtered off under reduced pressure and the crude solid subjected to silica-gel using $80 / 20 \%$ ethyl acetate/hexane mixture as eluent gave a $66: 34$ mixture of two isomers $1 E$ and $1 Z$ in good yield $65 \%$.

\section{(E)-6-(dimethylaminomethylene)-2,7-dimethyl-3-thioxo-3,4,5,6-tetrahydro-2H-[1,2,4]}

\section{triazepin-5-one $1 E$.}

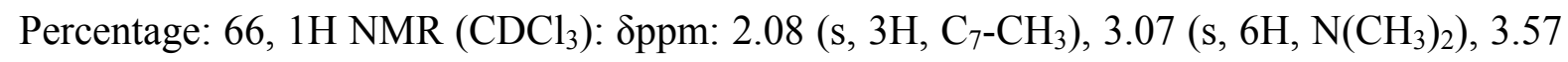
(s, 3H, $\left.\mathrm{N}_{2}-\mathrm{CH}_{3}\right), 7.55(\mathrm{~s}, 1 \mathrm{H}, \mathrm{H}-\mathrm{C}=), 7.84(\mathrm{~s}, 1 \mathrm{H}, \mathrm{NH}) .13 \mathrm{C} \mathrm{NMR}\left(\mathrm{CDCl}_{3}\right)$ : $\delta p p m:\left(\mathrm{C}_{7}-\mathrm{CH}_{3}\right)$, $44.95\left(\mathrm{~N}-\left(\mathrm{CH}_{3}\right)_{2}\right), 45.3\left(\mathrm{~N}_{2}-\mathrm{CH}_{3}\right), 154.5(\mathrm{H}-\mathrm{C}=), 96.1\left(\mathrm{C}_{6}\right), 164.2\left(\mathrm{C}_{7}\right), 168.2\left(\mathrm{C}_{5}\right), 177.4$ $\left(\mathrm{C}_{3}\right)$, Mass spectrum $(\mathrm{FAB}) \mathrm{m} / \mathrm{z}: 475[\mathrm{M}+\mathrm{H}]^{+}$

\section{(Z)-6-(dimethylaminomethylene)-2,7-dimethyl-3-thioxo-3,4,5,6-tetrahydro-2H-[1,2,4]}

\section{triazepin-5-one $1 Z$.}

Percentage: 34, 1H NMR $\left(\mathrm{CDCl}_{3}\right)$ : $\delta p p m: 2.18\left(\mathrm{~s}, 3 \mathrm{H}, \mathrm{C}_{7}-\mathrm{CH}_{3}\right), 3.07\left(\mathrm{~s}, 6 \mathrm{H}, \mathrm{N}\left(\mathrm{CH}_{3}\right)_{2}\right)$, 3.50(s, 3H, N $\left.{ }_{2}-\mathrm{CH} 3\right), 7.05$ (s, 1H, H-C=), 7.90 (s, 1H, NH). 13C NMR ( $\left.\mathrm{CDCl}_{3}\right): \delta p p m: 22.0$ $\left(\mathrm{C}_{7}-\mathrm{CH}_{3}\right), 44.9\left(\mathrm{~N}-\left(\mathrm{CH}_{3}\right)_{2}\right), 44.7\left(\mathrm{~N}_{2}-\mathrm{CH}_{3}\right), 154.1(\mathrm{H}-\mathrm{C}=), 96.5\left(\mathrm{C}_{6}\right), 163.6\left(\mathrm{C}_{7}\right), 164.9\left(\mathrm{C}_{5}\right)$, $177.2\left(\mathrm{C}_{3}\right)$, Mass spectrum $(\mathrm{FAB}) \mathrm{m} / \mathrm{z}: 475[\mathrm{M}+\mathrm{H}]^{+}$

\section{General procedure for preparation of products 3a-c, 4a-c and 5a-c}

To a solution of 1,2,4-triazepine 1 ( $5 \mathrm{mmol})$ and ethylhydrazono- $\alpha$-bromoglyoxylate $(5.5 \mathrm{mmol})$ in dry benzene $(30 \mathrm{ml})$, triethylamine $(7.2 \mathrm{mmol})$ dissolved in dry benzene $(10 \mathrm{ml})$ was added dropwise. After stirring for 72 hours at room temperature, the solvent was then removed under vacuum and the mixture was diluted with water $(25 \mathrm{ml})$ and extracted with dichloromethane $(3 \times 50 \mathrm{ml})$. The organic layers were dried over anhydrous sodium sulphate, concentrated under reduced pressure and the yellow crystalline product thus obtained 3a-c was further transformed to pure 4a-c and 5a-c compounds by chromatography on a silica gel column (eluent:hexane/ethylacetate,75/25). 
Ethyl (6E)-(2,7-dimethyl-5-oxo-6-((dimethylamino)methylene)-3,4,5,6-tetrahydro-2H[1,2,4]triazepine-3-spiro-2'-(3'-(p-tolyl)-2',3'-dihydro[1,3,4]thiadiazole-5'-carboxylate $3 a$.

1H NMR $\left(\mathrm{CDCl}_{3}\right): \delta$ ppm: 1.26-1.30 (m, 3H, $\left.\mathrm{COOCH}_{2} \underline{\mathrm{CH}_{3}}\right), 2.04\left(\mathrm{~s}, 3 \mathrm{H}, \mathrm{C}_{7}-\mathrm{CH}_{3}\right), 2.60(\mathrm{~s}$, $\left.3 \mathrm{H}, \mathrm{N}_{2}-\mathrm{CH}_{3}\right), 3.10\left(\mathrm{~s}, 6 \mathrm{H}, \mathrm{N}\left(\mathrm{CH}_{3}\right)_{2}\right), 4.22-4.33\left(\mathrm{~m}, 2 \mathrm{H},-\mathrm{CH}_{2}-\mathrm{O}\right), 7.75\left(\mathrm{~s}, 1 \mathrm{H}, \mathrm{C}_{6}=\mathrm{CH}\right), 6.40$ (s, 1H, NH), 6.92 (d, 2H, J=9.31Hz, H-Ar), 7.36 (d, 2H, J=9.31Hz, H-Ar). 13C NMR

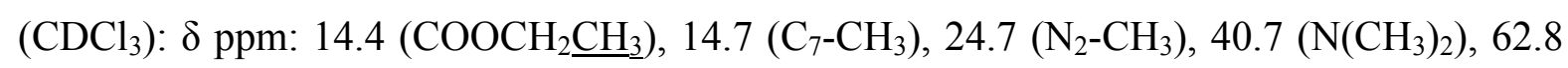
$\left(-\mathrm{CH}_{2}-\mathrm{O}\right), 98.5\left(\mathrm{C}_{2}\right), 118.2\left(\mathrm{C}_{6}\right), 117.4,129.7$ (CHAr), 134.4, $135.6(\mathrm{CAr}), 144.9\left(\mathrm{C}_{6}=\underline{\mathrm{CH}}\right)$, $154.5\left(\mathrm{C}_{7}\right), 160.4\left(\mathrm{C}_{5}\right), 165.6\left(\underline{\mathrm{C}=\mathrm{OC}_{2}} \mathrm{H}_{5}\right), 169.2\left(\mathrm{C}_{5}\right)$.

Ethyl (6Z)-(2,7-dimethyl-5-oxo-6-((dimethylamino)methylene)-3,4,5,6-tetrahydro-2H [1,2,4]triazepine-3-spiro-2'-(3'-(p-tolyl)-2',3'-dihydro[1,3,4]thiadiazole-5'-carboxylate $3 a$.

$1 \mathrm{H} \mathrm{NMR}\left(\mathrm{CDCl}_{3}\right): \delta$ ppm: 1.26-1.30 (m, 3H, $\left.\mathrm{COOCH}_{2} \underline{\mathrm{CH}}_{3}\right), 1.99$ (s, 3H, $\left.\mathrm{C}_{7}-\mathrm{CH}_{3}\right), 2.50$ (s, $\left.3 \mathrm{H}, \mathrm{N}_{2}-\mathrm{CH}_{3}\right), 3.10\left(\mathrm{~s}, 6 \mathrm{H}, \mathrm{N}\left(\mathrm{CH}_{3}\right)_{2}\right), 4.22-4.33\left(\mathrm{~m}, 2 \mathrm{H},-\mathrm{CH}_{2}-\mathrm{O}\right), 7.02\left(\mathrm{~s}, 1 \mathrm{H}, \mathrm{C}_{6}=\mathrm{CH}\right), 6.87$ (s,1H, NH), 6.87 (d, 2H, J=9.31Hz, H-Ar), 7.30 (d, 2H, J=9.31Hz, H-Ar). 13C NMR $\left(\mathrm{CDCl}_{3}\right)$ : $\delta$ ppm: $14.3\left(\mathrm{COOCH}_{2} \underline{\mathrm{CH}_{3}}\right), 14.4\left(\mathrm{C}_{7}-\mathrm{CH}_{3}\right), 21.4\left(\mathrm{~N}_{2}-\mathrm{CH}_{3}\right), 41.1\left(\mathrm{~N}_{\left.\left(\mathrm{CH}_{3}\right)_{2}\right), 63.5}\right.$ $\left(-\mathrm{CH}_{2}-\mathrm{O}\right), 98.2\left(\mathrm{C}_{2}\right), 117.6\left(\mathrm{C}_{6}\right) ; 117.2,129.3$ (CHAr); 134.5, $135.1(\mathrm{CAr}), 145.1\left(\mathrm{C}_{6}=\underline{\mathrm{CH}}\right)$, $155.3\left(\mathrm{C}_{7}\right), 162.0\left(\mathrm{C}_{5}\right), 165.7\left(\underline{\mathrm{C}=\mathrm{OC}_{2}} \mathrm{H}_{5}\right), 169.3\left(\mathrm{C}_{5}\right)$.

Ethyl (6E)-(2,7-dimethyl-5-oxo-6-((dimethylamino)methylene)-3,4,5,6-tetrahydro-2H [1,2,4]triazepine-3-spiro-2'-(3'-(p-chlorophenyl)-2',3'-dihydro[1,3,4]thiadiazole-5'carboxylate $3 \mathbf{b}$.

1H NMR $\left(\mathrm{CDCl}_{3}\right): \delta$ ppm: 1.35-1.37 (m, 3H, $\left.\mathrm{COOCH}_{2} \underline{\mathrm{CH}}_{3}\right), 2.07$ (s, 3H, $\left.\mathrm{C}_{7}-\mathrm{CH}_{3}\right), 2.58(\mathrm{~s}$, $\left.3 \mathrm{H}, \mathrm{N}_{2}-\mathrm{CH}_{3}\right), 3.14\left(\mathrm{~s}, 6 \mathrm{H}, \mathrm{N}\left(\mathrm{CH}_{3}\right)_{2}\right), 4.28-4.37$ (m, 2H, $\left.-\mathrm{CH}_{2}-\mathrm{O}\right), 7.72\left(\mathrm{~s}, 1 \mathrm{H}, \mathrm{C}_{6}=\mathrm{CH}\right), 6.40$ $(\mathrm{s}, 1 \mathrm{H}, \mathrm{NH}), 7.10(\mathrm{~d}, 2 \mathrm{H}, \mathrm{J}=9.31 \mathrm{~Hz}, \mathrm{H}-\mathrm{Ar}), 7.93$ (d, 2H, J=9.31Hz, H-Ar). 13C NMR $\left(\mathrm{CDCl}_{3}\right)$ : $\delta$ ppm: $\left.14.4\left(\mathrm{COOCH}_{2} \underline{\mathrm{CH}_{3}}\right), 14.6\left(\mathrm{C}_{7}-\mathrm{CH}_{3}\right), 24.6,\left(\mathrm{~N}_{2}-\mathrm{CH}_{3}\right), 40.3\left(\mathrm{~N}_{\left(\mathrm{CH}_{3}\right.}\right)_{2}\right), 62.8$ $\left(-\mathrm{CH}_{2}-\mathrm{O}\right), 97.2\left(\mathrm{C}_{2}\right), 118.9\left(\mathrm{C}_{6}\right), 121.3,125.5$ (CHAr), 130.4, $136.6(\mathrm{CAr}), 144.2\left(\mathrm{C}_{6}=\underline{\mathrm{CH}}\right)$, $152.8\left(\mathrm{C}_{7}\right), 159.3\left(\mathrm{C}_{5},\right), 165.8\left(\underline{\mathrm{C}=\mathrm{OC}_{2}} \mathrm{H}_{5}\right), 169.8\left(\mathrm{C}_{5}\right)$.

Ethyl (6Z)-(2,7-dimethyl-5-oxo-6-((dimethylamino)methylene)-3,4,5,6-tetrahydro-2H [1,2,4]triazepine-3-spiro-2'-(3'-(p-chlorophenyl)-2',3'-dihydro[1,3,4]thiadiazole-5'carboxylate $3 \mathbf{b}$. 
1H NMR $\left(\mathrm{CDCl}_{3}\right): \delta$ ppm: 1.35-1.37 (m, 3H, $\left.\mathrm{COOCH}_{2} \underline{\mathrm{CH}}_{3}\right), 2.00\left(\mathrm{~s}, 3 \mathrm{H}, \mathrm{C}_{7}-\mathrm{CH}_{3}\right), 2.56$ (s, $\left.3 \mathrm{H}, \mathrm{N}_{2}-\mathrm{CH}_{3}\right), 3.14\left(\mathrm{~s}, 6 \mathrm{H}, \mathrm{N}\left(\mathrm{CH}_{3}\right)_{2}\right), 4.28-4.37$ (m, 2H, $\left.-\mathrm{CH}_{2}-\mathrm{O}\right), 7.01$ (s, 1H, $\left.\mathrm{C}_{6}=\mathrm{CH}\right), 6.73$ (s,1H, NH), 7.13 (d, 2H, J=9.31Hz, H-Ar), 7.87 (d, 2H, J=9.31Hz, H-Ar). 13C NMR $\left(\mathrm{CDCl}_{3}\right)$ : $\delta$ ppm: $14.2\left(\mathrm{COOCH}_{2} \underline{\mathrm{CH}_{3}}\right), 14.3\left(\mathrm{C}_{7}-\mathrm{CH}_{3}\right) ; 21.8,\left(\mathrm{~N}_{2}-\mathrm{CH}_{3}\right), 40.8\left(\mathrm{~N}_{\left.\left(\mathrm{CH}_{3}\right)_{2}\right), 63.6}\right.$ (- $\left.\mathrm{CH}_{2}-\mathrm{O}\right), 98.3\left(\mathrm{C}_{2}\right)$; $118.4\left(\mathrm{C}_{6}\right), 121.1,125.0$ (CHAr), 130.5, $137.2(\mathrm{CAr}), 144.5\left(\mathrm{C}_{6}=\underline{\mathrm{C}} \mathrm{H}\right)$, $153.7\left(\mathrm{C}_{7}\right) ; 160.0\left(\mathrm{C}_{5},\right), 165.6\left(\underline{\mathrm{C}=\mathrm{OC}_{2}} \mathrm{H}_{5}\right), 169.9\left(\mathrm{C}_{5}\right)$.

Ethyl (6E)-(2,7-dimethyl-5-oxo-6-((dimethylamino)methylene)-3,4,5,6-tetrahydro-2H [1,2,4]triazepine-3-spiro-2'-(3'-(p-nitrophenyl)-2',3'-dihydro[1,3,4]thiadiazole-5'carboxylate $3 c$.

1H NMR ( $\left.\mathrm{CDCl}_{3}\right)$ : $\delta$ ppm: 1.36-1.39 (m, 3H, $\left.\mathrm{COOCH}_{2} \underline{\mathrm{CH}}_{3}\right), 2.08\left(\mathrm{~s}, 3 \mathrm{H}, \mathrm{C}_{7}-\mathrm{CH}_{3}\right), 2.60$ (s, $\left.3 \mathrm{H}, \mathrm{N}_{2}-\mathrm{CH}_{3}\right), 3.15\left(\mathrm{~s}, 6 \mathrm{H}, \mathrm{N}\left(\mathrm{CH}_{3}\right)_{2}\right), 4.31-4.41\left(\mathrm{~m}, 2 \mathrm{H},-\mathrm{CH}_{2}-\mathrm{O}\right), 7.75\left(\mathrm{~s}, 1 \mathrm{H}, \mathrm{C}_{6}=\mathrm{CH}\right), 6.45$ $(\mathrm{s}, 1 \mathrm{H}, \mathrm{NH}), 7.79$ (d, 2H, J=9.35Hz, H-Ar), 8.11 (d, 2H, J=9.35Hz, H-Ar). 13C NMR

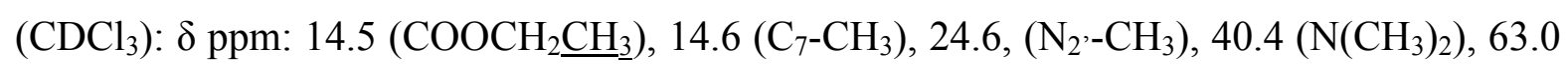
(-CH $2-\mathrm{O}), 97.9\left(\mathrm{C}_{2}\right), 118.6\left(\mathrm{C}_{6}\right), 118.3,125.3$ (CHAr), 138.4, $143.4(\mathrm{CAr}), 145.8\left(\mathrm{C}_{6}=\underline{\mathrm{CH}}\right)$, $153.9\left(\mathrm{C}_{7}\right), 160.1\left(\mathrm{C}_{5}\right), 165.7\left(\underline{\mathrm{C}=\mathrm{OC}_{2}} \mathrm{H}_{5}\right), 169.7\left(\mathrm{C}_{5}\right)$.

Ethyl (6Z)-(2,7-dimethyl-5-oxo-6-((dimethylamino)methylene)-3,4,5,6-tetrahydro-2H [1,2,4]triazepine-3-spiro-2'-(3'-(p-nitrophenyl)-2',3'-dihydro[1,3,4]thiadiazole-5'carboxylate $3 c$.

1H NMR $\left(\mathrm{CDCl}_{3}\right): \delta$ ppm: 1.36-1.39 (m, 3H, $\left.\mathrm{COOCH}_{2} \underline{\mathrm{CH}}_{3}\right), 2.00\left(\mathrm{~s}, 3 \mathrm{H}, \mathrm{C}_{7}-\mathrm{CH}_{3}\right), 2.58(\mathrm{~s}$, $\left.3 \mathrm{H}, \mathrm{N}_{2}-\mathrm{CH}_{3}\right), 3.15\left(\mathrm{~s}, 6 \mathrm{H}, \mathrm{N}\left(\mathrm{CH}_{3}\right)_{2}\right), 4.31-4.41\left(\mathrm{~m}, 2 \mathrm{H},-\mathrm{CH}_{2}-\mathrm{O}\right), 7.07\left(\mathrm{~s}, 1 \mathrm{H}, \mathrm{C}_{6}=\mathrm{CH}\right), 6.76$ (s,1H, NH), 7.81 (d, 2H, J=9.33Hz, H-Ar), 8.05 (d, 2H, J=9.331Hz, H-Ar). 13C NMR

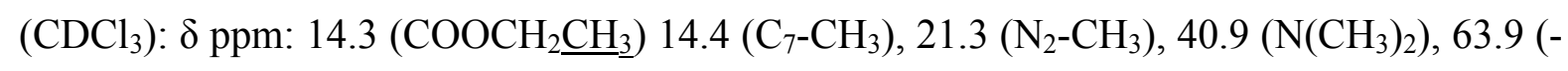
$\left.\mathrm{CH}_{2}-\mathrm{O}\right), 98.6\left(\mathrm{C}_{2}\right), 118.1\left(\mathrm{C}_{6}\right), 118.2,124.8$ (CHAr), 138.5, 144.0 (CAr), $146.0\left(\mathrm{C}_{6}=\underline{\mathrm{CH}}\right)$, $154.7\left(\mathrm{C}_{7}\right), 161.8\left(\mathrm{C}_{5}\right), 165.8\left(\underline{\mathrm{C}=\mathrm{OC}_{2}} \mathrm{H}_{5}\right), 169.8\left(\mathrm{C}_{5}\right)$.

Ethyl (E)-2-(4'-formyl-1',3'-dimethyl-1H-[1,2]pyrazol-5'-ylimino)-3-p-tolyl-2,3-dihydro $[1,3,4]$ thiadiazole-5-carboxylate 4 a.

mp: $151-152^{\circ} \mathrm{C}(\mathrm{EtOH}) .1 \mathrm{H} \mathrm{NMR}\left(\mathrm{CDCl}_{3}\right)$ : $\delta p p m: 1.32$ (t, 3H, J=7.19 Hz,-CH$\left.-\mathrm{CH}_{2}\right), 2.33$ (s, 3H, Ar- $\mathrm{CH}_{3}$ ), 2.38 (s, 3H, C 3 ,- $\mathrm{CH}_{3}$ ), 3.50 (s, 3H, N,$-\mathrm{CH}_{3}$ ), 4.37 (q, 2H, J=7.19Hz, -O-

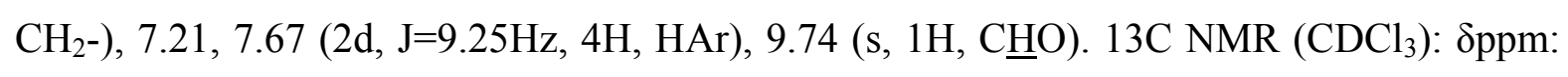
$13.4\left(\mathrm{COOCH}_{2} \underline{\mathrm{CH}}_{3}\right), 14.5\left(\mathrm{C}_{3},-\underline{\mathrm{CH}}_{3}\right), 21.5\left(\mathrm{Ar}-\mathrm{CH}_{3}\right), 34.8\left(\mathrm{~N}_{1},-\mathrm{CH}_{3}\right), 63.6\left(\mathrm{O}-\mathrm{CH}_{2}\right), 108.8$ 
$\left(\mathrm{C}_{4}{ }^{\prime}\right), 124.5,129.9,135.8,138.9(\mathrm{CAr}), 141.5\left(\mathrm{C}_{3^{\prime}}\right), 151.3,151.4\left(\mathrm{C}_{5}, \mathrm{C}_{5}\right), 158.1\left(\underline{\mathrm{CO}}{ }_{2} \mathrm{Et}\right)$, $162.0\left(\mathrm{C}_{2}\right), 183.0(\underline{\mathrm{C}} \mathrm{HO})$. Mass spectrum (FAB): m/z $386[\mathrm{M}+\mathrm{H}]^{+} 100 \%$.

Ethyl (E)-2-(1',3'-dimethyl-1H-[1,2]pyrazol-4'-ylcarbonylimino)-3-p-tolyl-2,3-dihydro $[1,3,4]$ thiadiazole-5-carboxylate 5 a.

mp: $183-184^{\circ} \mathrm{C}(\mathrm{EtOH}) .1 \mathrm{H} \mathrm{NMR}\left(\mathrm{CDCl}_{3}\right)$ : $\delta \mathrm{ppm}: 1.44$ (t, 3H, J=7.14 Hz, $\left.-\mathrm{CH}_{2}-\mathrm{CH}_{3}\right), 2.45$, $2.50\left(2 \mathrm{~s}, 6 \mathrm{H}, \mathrm{Ar}-\mathrm{CH}_{3}, \mathrm{C}_{3},-\mathrm{CH}_{3}\right), 3.83\left(\mathrm{~s}, 3 \mathrm{H}, \mathrm{N}_{1},-\mathrm{CH}_{3}\right), 4.49$ (q, 2H, J=7.14Hz, -O- $\mathrm{CH}_{2}-$ ), 7.33, 7.75 (2d, J=9.19Hz, 4H, HAr), 7.84 (s, 1H, $\left.\mathrm{C}_{5},-\underline{\mathrm{H}}\right) .13 \mathrm{C}$ NMR ( $\left.\mathrm{CDCl}_{13}\right): \delta p p m: 14.3$,

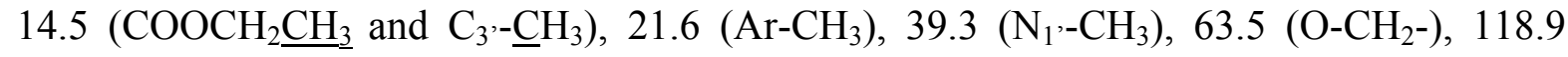
$\left(\mathrm{C}_{4}{ }^{\prime}\right), 125.4,129.8,135.7,139.2$ (CAr), $136.7\left(\mathrm{C}_{5}\right)$, 147.9, $151.9\left(\mathrm{C}_{3}, \mathrm{C}_{5}\right), 159.0,164.9$ $\left(\mathrm{CO}_{2} \mathrm{Et}, \mathrm{C}_{2}\right), 171.8(\mathrm{CO})$. Mass spectrum (FAB): m/z $386[\mathrm{M}+\mathrm{H}]^{+} 100 \%$.

Ethyl (E)-2-(4'-formyl-1',3'-dimethyl-1H-[1,2]pyrazol-5'-ylimino)-3-p-chlorophenyl2,3-dihydro[1,3,4]thiadiazole-5-carboxylate $4 \mathrm{~b}$.

mp: $158-159^{\circ} \mathrm{C}(\mathrm{EtOH}) .1 \mathrm{H} \mathrm{NMR}\left(\mathrm{CDCl}_{3}\right): \delta p p m: 1.42\left(\mathrm{t}, 3 \mathrm{H}, \mathrm{J}=7.18 \mathrm{~Hz},-\mathrm{CH}_{2}-\underline{\mathrm{C}}_{3}\right), 2.48$ (s, $\left.3 \mathrm{H}, \mathrm{C}_{3},-\mathrm{CH}_{3}\right), 3.60$ (s, 3H, N $\left.{ }_{1}-\mathrm{CH}_{3}\right), 4.45$ (q, $2 \mathrm{H}, \mathrm{J}=7.18 \mathrm{~Hz},-\mathrm{O}-\mathrm{CH}_{2}-$ ), 7.49- 7.87 (2d, $\mathrm{J}=9.24 \mathrm{~Hz}, 4 \mathrm{H}, \mathrm{HAr}), 9.80$ (s, 1H, $\underline{\mathrm{HO}}) .13 \mathrm{C} \mathrm{NMR}\left(\mathrm{CDCl}_{3}\right): \delta \mathrm{ppm}: 13.3\left(\underline{\mathrm{COOC}_{2}} \mathrm{H}_{5}\right), 14.5$ $\left(\mathrm{C}_{3},-\mathrm{CH}_{3}\right), 34.9\left(\mathrm{~N}_{1},-\mathrm{CH}_{3}\right), 63.9\left(\mathrm{O}-\mathrm{CH}_{2}\right), 109.1\left(\mathrm{C}_{4}\right), 125.6,126.5,134.3,136.8(\mathrm{CAr})$, $142.3\left(\mathrm{C}_{3}{ }^{\prime}\right), 150.7,151.4\left(\mathrm{C}_{5}, \mathrm{C}_{5}\right), 158.0\left(\underline{\mathrm{CO}}_{2} \mathrm{Et}\right), 161.7\left(\mathrm{C}_{2}\right), 183.2$ (ㅌHO). Mass spectrum (FAB): m/z $406[\mathrm{M}+\mathrm{H}]^{+} 100 \%$.

Ethyl (E)-2-(1',3'-dimethyl-1H-[1,2]pyrazol-4'-ylcarbonylimino)-4-p-chlorophenyl-2,3dihydro[1,3,4]thiadiazole-5-carboxylate $5 b$.

mp: $199-200^{\circ} \mathrm{C}(\mathrm{EtOH}) .1 \mathrm{H} \mathrm{NMR}\left(\mathrm{CDCl}_{3}\right): \delta p p m: 1.47$ (t, 3H, J=7.13Hz, $\left.-\mathrm{CH}_{2}-\underline{C}_{3}\right), 2.54$ (s, $\left.3 \mathrm{H}, \mathrm{C}_{3},-\mathrm{CH}_{3}\right), 3.88$ (s, 3H, N $\left.{ }_{1}, \mathrm{CH}_{3}\right), 4.52$ (q, $\left.2 \mathrm{H}, \mathrm{J}=7.13 \mathrm{~Hz},-\mathrm{O}-\mathrm{CH}_{2}-\right)$, 7.55-7.90 (2d, $\mathrm{J}=9.18 \mathrm{~Hz}, 4 \mathrm{H}, \mathrm{HAr}), 7.86\left(\mathrm{~s}, 1 \mathrm{H}, \mathrm{C}_{5},-\underline{\mathrm{H}}\right) .13 \mathrm{C}$ NMR $\left(\mathrm{CDCl}_{3}\right): \delta p p m: 14.3,14.6$ $\left(\mathrm{COOCH}_{2} \underline{\mathrm{CH}}_{3}\right.$ and $\left.\mathrm{C}_{3},-\mathrm{CH}_{3}\right), 39.4\left(\mathrm{~N}_{1},-\mathrm{CH}_{3}\right), 63.7\left(\mathrm{O}_{-} \mathrm{CH}_{2}-\right), 118.7\left(\mathrm{C}_{4}\right), 126.5,129.4$, 134.8, 137.6 (CAr), $135.7\left(\mathrm{C}_{5}\right)$, 148.4, $151.9\left(\mathrm{C}_{3}, \mathrm{C}_{5}\right), 158.8,164.8\left(\mathrm{CO}_{2} \mathrm{Et}, \mathrm{C}_{2}\right), 171.7$ (CO). Mass spectrum (FAB): m/z $406[\mathrm{M}+\mathrm{H}]^{+} 100 \%$.

Ethyl (E)-2-(4'-formyl-1',3'-dimethyl-1H-[1,2]pyrazol-5'-ylimino)- 3-p-nitrophenyl-2,3dihydro[1,3,4]thiadiazole-5-carboxylate 4c.

mp: $167-169^{\circ} \mathrm{C}(\mathrm{EtOH}) .1 \mathrm{H} \mathrm{NMR}\left(\mathrm{CDCl}_{3}\right): \delta p p m: 1.43$ (t, 3H, J=7.21Hz, $\left.-\mathrm{CH}_{2}-\underline{C}_{3}\right), 2.48$ (s, 3H, $\left.\mathrm{C}_{3},-\mathrm{CH}_{3}\right), 3.61$ (s, 3H, $\left.\mathrm{N}_{1},-\mathrm{CH}_{3}\right), 4.49$ (q, $\left.2 \mathrm{H}, \mathrm{J}=7.21 \mathrm{~Hz},-\mathrm{O}-\mathrm{CH}_{2}-\right)$, 8.28-8.36 (2m, 


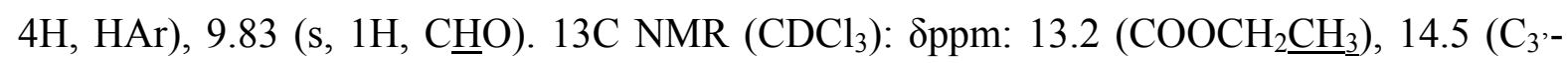
$\left.\underline{\mathrm{CH}}_{3}\right), 35.0\left(\mathrm{~N}_{1},-\underline{\mathrm{CH}}_{3}\right), 64.1\left(-\mathrm{O}-\mathrm{CH}_{2}\right), 109.3\left(\mathrm{C}_{4}\right), 123.8,124.9,143.4,146.6(\mathrm{CAr}), 143.6$

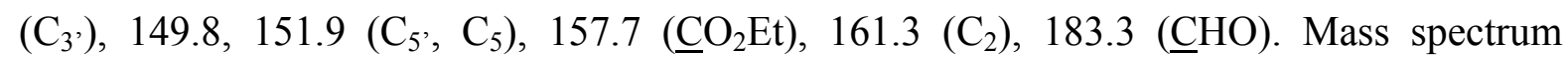
(FAB): $\mathrm{m} / \mathrm{z} 417[\mathrm{M}+\mathrm{H}]^{+} 100 \%$.

Ethyl (E)-2-(1',3'-dimethyl-1H-[1,2]pyrazole-4'-carbonylimino)-3-p-nitro-phenyl-2,3dihydro[1,3,4]thiadiazole-5-carboxylate $5 \mathrm{c}$.

mp: $213-214^{\circ} \mathrm{C}(\mathrm{EtOH}) .1 \mathrm{H} \mathrm{NMR}\left(\mathrm{CDCl}_{3}\right): \delta \mathrm{ppm}: 1.47\left(\mathrm{t}, 3 \mathrm{H}, \mathrm{J}=7.17 \mathrm{~Hz},-\mathrm{CH}_{2}-\underline{\mathrm{C}}_{3}\right), 2.54$ (s, $\left.3 \mathrm{H}, \mathrm{C}_{3},-\mathrm{CH}_{3}\right), 3.88$ (s, 3H, N $\left.{ }_{1}-\mathrm{CH}_{3}\right), 4.53$ (q, $2 \mathrm{H}, \mathrm{J}=7.17 \mathrm{~Hz},-\mathrm{O}-\mathrm{CH}_{2}$ ), $8.36-8.44(2 \mathrm{~m}$, 4H, HAr), 7.89 (s, 1H, $\left.\mathrm{C}_{5}, \underline{-} \underline{\mathrm{H}}\right)$. 13C NMR $\left(\mathrm{CDCl}_{3}\right)$ : $\delta \mathrm{ppm}: 14.3,14.5\left(\mathrm{COOCH}_{2} \underline{\mathrm{CH}}_{3}\right)$ and $\left.\mathrm{C}_{3},-\underline{C H}_{3}\right), 39.4\left(\mathrm{~N}_{1},-\mathrm{CH}_{3}\right), 63.9\left(\mathrm{O}_{-} \mathrm{CH}_{2}\right), 118.3\left(\mathrm{C}_{4}{ }^{\prime}\right), 124.8,125.2,143.9,147.0$ (CAr), $135.7\left(\mathrm{C}_{5}\right), 149.3,152.2\left(\mathrm{C}_{3}, \mathrm{C}_{5}\right), 158.6,164.7\left(\mathrm{CO}_{2} \mathrm{Et}, \mathrm{C}_{2}\right), 171.5(\mathrm{CO})$. Mass spectrum (FAB): $\mathrm{m} / \mathrm{z} 417[\mathrm{M}+\mathrm{H}]^{+} 100 \%$.

\section{General procedure for preparation of products 3d-f, 4d-f and $5 d-f$}

To a solution of 5mmol. of dimethylaminomethylene-3-thioxo-1,2,4-triazepin-5-one $\mathbf{1}$ and $5 \mathrm{mmol}$. of $\alpha$-chloroarylidenephenylhydrazone in $20 \mathrm{ml}$ of dry benzene, was added $1.6 \mathrm{ml}$ of dry triethylamine dissolved in dry benzene. After stirring for 72 hours at room temperature, the reaction mixture was extracted with benzene $(3 \times 50 \mathrm{ml})$ and the organic layers were dried over anhydrous sodium sulphate and evaporated under reduced pressure. The yellow crude solid thus obtained 3d-f were further transformed to pure 4d-f and 5d-f compounds by chromatography on a silica gel column using ethyl acetate/ hexane as eluent.

\section{(E)-2-(4'-formyl-1',3'-dimethyl-1H-[1,2]pyrazol-5'-ylimino)-5-p-tolyl-3-phenyl-2,3-}

\section{dihydro[1,3,4]thiadiazole $4 \mathrm{~d}$}

mp: $141-142^{\circ} \mathrm{C}(\mathrm{EtOH}) .1 \mathrm{H} \mathrm{NMR}\left(\mathrm{CDCl}_{3}\right): \delta(\mathrm{ppm}): 2.39$ (1s, 3H, $\left.\mathrm{Ar}-\mathrm{CH}_{3}\right), 2.46\left(\mathrm{~s}, 3 \mathrm{H}, \mathrm{C}_{3}\right.$,$\left.\mathrm{CH}_{3}\right), 3.60$ (s, 3H, $\mathrm{N}_{1},-\mathrm{CH}_{3}$ ), 7.23-8.01 (m, 9H, HAr), 9.80 (s, 1H, CㅌO). 13C NMR $\left(\mathrm{CDCl}_{3}\right): \delta(\mathrm{ppm}): 13.5\left(\mathrm{C}_{3},-\mathrm{CH}_{3}\right), 21.5\left(\mathrm{Ar}-\mathrm{CH}_{3}\right), 34.4\left(\mathrm{~N}_{1},-\mathrm{CH}_{3}\right), 108.4\left(\mathrm{C}_{4}{ }^{\prime}\right), 123.4,126.2$, 127.4, 128.9, 129.8 (5 $\underline{\mathrm{CH}}-\mathrm{Ar}), 126.8,138.8,141.7$ (3 CAr), 149.6, 150.7, $153.0\left(\mathrm{C}_{3}, \mathrm{C}_{5}\right.$, $\left.\mathrm{C}_{5}\right), 161.2\left(\mathrm{C}_{2}\right), 183.0$ (때O).

Mass spectrum, $(\mathrm{m} / \mathrm{z}): 389[\mathrm{M}]^{+}(100 \%), 208,91$.

(E)-2-(1',3'-dimethyl-1H-[1,2]pyrazol-4'-ylcarbonylimino)-3-p-tolyl-5-phenyl-2,3dihydro- $[1,3,4]$ thiadiazole $5 \mathrm{~d}$. 


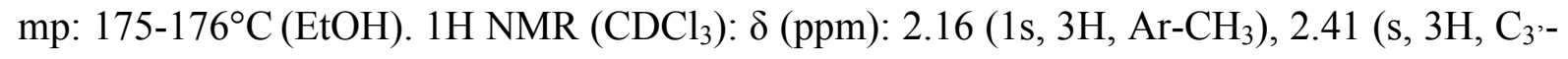
$\left.\mathrm{CH}_{3}\right), 3.83\left(\mathrm{~s}, 3 \mathrm{H}, \mathrm{N}_{1},-\mathrm{CH}_{3}\right), 7.86\left(\mathrm{~s}, 1 \mathrm{H}, \mathrm{C}_{5},-\mathrm{H}\right), 7.26-8.00(\mathrm{~m}, 9 \mathrm{H}, \mathrm{HAr}) . \quad 13 \mathrm{C}$ NMR $\left(\mathrm{CDCl}_{3}\right): \delta(\mathrm{ppm}): 13.9\left(\mathrm{C}_{3}, \mathrm{CH}_{3}\right), 21.5\left(\mathrm{Ar}-\mathrm{CH}_{3}\right), 38.9\left(\mathrm{~N}_{1},-\mathrm{CH}_{3}\right), 118.9\left(\mathrm{C}_{4}{ }^{\prime}\right), 124.7,126.5$, 127.9, 128.7, 129.9 (5 CH-Ar), 127.2, 139.3, 141.6 (3 CAr), 135.1 ( $\mathrm{C}_{5}$ ) $)$ 151.3, $156.3\left(\mathrm{C}_{3}\right.$ ', $\left.\mathrm{C}_{5}\right), 163.5\left(\mathrm{C}_{2}\right), 171.3(\mathrm{CO})$.

Mass spectrum, (m/z): $389[\mathrm{M}]^{+}$123(100\%), 280, 208, 91.

(E)-2-(4'-formyl-1',3'-dimethyl-1H-[1,2]pyrazol-5'-ylimino)-3-p-chlorophenyl-5-phenyl2,3-dihydro[1,3,4]thiadiazole 4e

mp: $165-166^{\circ} \mathrm{C}(\mathrm{EtOH}) .1 \mathrm{H} \mathrm{NMR}\left(\mathrm{CDCl}_{3}\right): \delta(\mathrm{ppm}): 2.55\left(1 \mathrm{~s}, 3 \mathrm{H}, \mathrm{C}_{3},-\mathrm{CH}_{3}\right), 3.60(1 \mathrm{~s}, 3 \mathrm{H}$, $\left.\mathrm{N}_{1},-\mathrm{CH}_{3}\right)$, 7.35-8.00 (m, 9H, HAr), 9.82 (s, 1H, CHO). RMN 13C NMR $\left(\mathrm{CDCl}_{3}\right)$ : $13.8\left(\mathrm{C}_{3},-\right.$ $\left.\mathrm{CH}_{3}\right), 34.8\left(\mathrm{~N}_{1},-\mathrm{CH}_{3}\right), 108.9\left(\mathrm{C}_{4}\right), 123.9,127.9,128.0,129.4,129.8$ (5CH-Ar), 128.5, 137.7, 139.0 (3 CAr), 148.7, 151.3, 152.8, $161.2\left(\mathrm{C}_{3}, \mathrm{C}_{5}, \mathrm{C}_{5}, \mathrm{C}_{2}\right), 183.3(\mathrm{CHO})$.

Mass spectrum, (m/z): $409[\mathrm{M}]^{+}, 389,91(100 \%)$.

(E)-2-(1',3'-dimethyl-1H-[1,2]pyrazol-4'-ylcarbonylimino)-5-p-chlorophenyl-3-phenyl2,3-dihydro[1,3,4]thiadiazole 5e.

mp: $195-196^{\circ} \mathrm{C}(\mathrm{ETOH}) .1 \mathrm{H} \mathrm{NMR}\left(\mathrm{CDCl}_{3}\right): \delta(\mathrm{ppm}): 2.52\left(\mathrm{~s}, 3 \mathrm{H}, \mathrm{C}_{3}, \mathrm{CH}_{3}\right), 3.84(\mathrm{~s}, 3 \mathrm{H}$, $\left.\mathrm{N}_{1},-\mathrm{CH}_{\underline{3}}\right), 7.82\left(\mathrm{~s}, 1 \mathrm{H}, \mathrm{C}_{5},-\mathrm{H}\right), 7.26-7.99$ (m, 9H, HAr). 13C NMR $\left(\mathrm{CDCl}_{3}\right): \delta(\mathrm{ppm}): 14.3$ $\left(\mathrm{C}_{3},-\mathrm{CH}_{3}\right), 39.3\left(\mathrm{~N}_{1},-\mathrm{CH}_{3}\right), 119.1\left(\mathrm{C}_{4}\right), 125.0,128.2,128.5,129.2,129.9$ (5 CH-Ar), 128.9, 137.7, 139.6 (3 CAr), 135.6 ( $\left.\mathrm{C}_{5},\right), 151.8,155.1\left(\mathrm{C}_{3}, \mathrm{C}_{5}\right), 163.7\left(\mathrm{C}_{2}\right), 171.7(\mathrm{CO})$.

Mass spectrum, (m/z): $409[\mathrm{M}]^{+}, 300,123(100 \%), 91$.

(E)-2-(4'-formyl-1',3'-dimethyl-1H-[1,2]pyrazol-5'-ylimino)-2,3-dihydro-5-p-nitrophenyl-3-phenyl[1,3,4]thiadiazole $4 \mathrm{f}$

mp : $144-146^{\circ} \mathrm{C}(\mathrm{EtOH}) .1 \mathrm{H} \mathrm{NMR}\left(\mathrm{CDCl}_{3}\right): \delta(\mathrm{ppm}): 2.48\left(\mathrm{~s}, 3 \mathrm{H}, \mathrm{C}_{3}, \mathrm{CH}_{3}\right), 3.61\left(\mathrm{~s}, 3 \mathrm{H}, \mathrm{N}_{1}\right.$ '$\mathrm{CH}_{\underline{3}}$ ), 7.26-8.33 (m, 9H, HAr), 9.83 (s, 1H, C트). 13C NMR $\left(\mathrm{CDCl}_{3}\right): \delta(\mathrm{ppm}): 13.2\left(\mathrm{C}_{3},-\right.$ $\left.\mathrm{CH}_{3}\right), 34.5\left(\mathrm{~N}_{1},-\mathrm{CH}_{3}\right), 108.6\left(\mathrm{C}_{4},\right)$ 123.7, 124.4, 127.0, 128.0, 129.1 (5 CH-Ar), 135.2, 138.3, 147.0 (3 CAr); $149.0\left(\mathrm{C}_{3},\right), 151.1,151.4\left(\mathrm{C}_{5}, \mathrm{C}_{5}\right), 160.5\left(\mathrm{C}_{2}\right), 182.4$ (ㅌHO).

Mass spectrum, (m/z): $420[\mathrm{M}]^{+}, 123(100 \%), 91$.

(E)-2-(1',3'-dimethyl-1H-[1,2]pyrazol-4'-ylcarbonylimino)-3-p-nitrophenyl-5-phenyl2,3-dihydro[1,3,4]thiadiazole $5 f$. 
mp: $210-211^{\circ} \mathrm{C}(\mathrm{EtOH}) .1 \mathrm{H} \mathrm{NMR}\left(\mathrm{CDCl}_{3}\right): \delta(\mathrm{ppm}): 2.53\left(\mathrm{~s}, 3 \mathrm{H}, \mathrm{C}_{3}, \mathrm{CH}_{3}\right), 3.85\left(\mathrm{~s}, 3 \mathrm{H}, \mathrm{N}_{1}\right.$,$\left.\mathrm{CH}_{3}\right), 7.88$ (s, 1H, $\left.\mathrm{C}_{5},-\mathrm{H}\right), 7.26-8.38$ (m, 9H, HAr). 13C NMR $\left(\mathrm{CDCl}_{3}\right): \delta(\mathrm{ppm}): 13.9\left(\mathrm{C}_{3},-\right.$ $\left.\mathrm{CH}_{3}\right), 39.0\left(\mathrm{~N}_{1},-\mathrm{CH}_{3}\right), 118.5\left(\mathrm{C}_{4}{ }^{\prime}\right), 124.5,124.7,127.3,128.4,128.9$ (5 CH-Ar), 135.8, 139.0, 149.0 (3 CAr), $135.3\left(\mathrm{C}_{5}\right), 151.5,153.4\left(\mathrm{C}_{3}, \mathrm{C}_{5}\right), 163.4\left(\mathrm{C}_{2}\right), 171.4(\mathrm{C}=\mathrm{O})$.

Mass spectrum, (m/z): $420[\mathrm{M}]^{+}(100 \%), 91$.

\section{Aknowledgements.}

This work has been partially supported by the Ministerio de Educación y Ciencia of the Spanish Government (project CTQ2006-14297/BQU) and the Agencia Española de Cooperación Internacional (project A/6409/06). The authors thank also S.C.S.I.E. (X-Ray section) of University of Valencia for provision of the X-ray crystallographic facilities.

\section{References}

1 Vida JA, Medicinal Chemistry Part III; Wolf MW, Burger A, Eds, John Wiley and Sons: New York, 1981.

2 Nagaraja GK, Kumaraswamy MN, Vaidya VP, Mahadevan KM, Arkivoc, 2006, 211 219.

3 Michelini S, Cassano GB, Frare F, Perugi G, Pharmacopsychiatry 1996, 29, 127- 134.

4 Michelini S, Cassano GB, Frare F, Perugi G. Pharmacopsychiatry 1996; 29: 127-134;

5 Zellou A, Charrah Y, Essassi E-M, Hassar M. Ann. Pharm. Fr. 1998; 56: 175-180.

6 Ryng S, Zimecki M, Maczynski M, Chodaczek G, Kocieba M, Pharmacological Reports 2005, 57, 195-202.

7 Langlois N, Rojas-Rousseau A, Gaspard C, Werner GH, Darro F, Kiss R, J. Med. Chem. 2001, 44, 3754-3757.

8 Di Braccio M, Grossi G, Roma G, Vargiu L, Mura M, Marongiu ME, Eur. J. Med. Chem. 2001, 36, 935-949.

9 Atwal KS, Bergey JL, Hedberg A, Moreland S, J. Med. Chem. 1987, 30, 635-640; Matsuhisa A, Koshio H, Sakamoto K, Taniguchi N, Yatsu T, Tanaka A, Chem. Pharm. Bull. 1998, 46, 1566-1579.

10 Matsuhisa A, Koshio H, Sakamoto K, Taniguchi N, Yatsu T, Tanaka A, Chem. Pharm. Bull. 1998, 46, 1566-1579

11 Forhberg P, Nuhu P, Heterocycles 1996, 43, 2549-2552

12 Gupta SB, Gkhar HK, Indian J. Heterocycl. Chem. 1997, 7, 157-158 
13 a) Deohate PP, Deahate JP, Berad BN, Asian J. Chem. 2004, 16 773-778; b) Deohate PP, Berad BN, Oriantal J. Chem. 2004, 20, 139-142.

14 Bellantuono C, Reggi G, Grattini S, Tognoni G, Drugs.1980, 19, 195-219.

15 Bartsh H, Erker T, J. Heterocycl. Chem. 1988, 25, 1151-1154.

16 Ait Itto MY, Hasnaoui A, Riahi A. Lavergne J-P. Tetrahedron Lett. 1997; 38: 20872090 .

17 (a) Cortes EC, Mellado OG, Hernadez Cruz, E. J. Heterocyclic Chem. 1999; 36: 477480; (b) El Messaoudi T, El Messaoudi M, Zair T, Hasnaoui A, Esseffar M. Synthetic Comm. 2002; 32: 1815-1820.

18 Esseffar M, Jalal R, El Messaoudi M, El Mouhtadi M, J. Mol. struct. (Theochem) 1998, 433, 301-309.

19 Jalal R, El Messaoudi M, Esseffar M, J. Mol. Struct. (Theochem) 2002, 580, 183-192.

20 Jalal R, El Messaoudi M, Hasnaoui A, Esseffar M, Selkti M, Lavergne J-P, Compain P, New J. Chem. 2002, 26, 1545-1548.

21 Azzouzi S, Jalal R, El Messaoudi M, Domingo LR, Esseffar M, and Aurell MJ, J. Phys. Org. Chem., 2007, 20, 245-254.

22 Azzouzi S, El Messaoudi M, Esseffar M, Jalal R, Cano FH, Apreda-Rojas MC, Domingo LR, J. Phys. Org. Chem , 2005, 18, 522-528.

23 (a) Torssell KBG, "Organic Nitro Chemistry Series". Ed. Feuer H, VCH Publishers, Inc. 1988, Indiana (USA); (b) Maguet M, Poirier Y, Teste J, "Heterocyclic sulfur compounds VI. Synthesis of derivatives of 1,3,4-thiadiazoline”, Bull. Soc. Chim. Fr. 1970, 1503-1509.

24 Firsova 0V, Dolgushina TS, Polukeev BA, Zavodnik VE, Stash AI, Belskii VK, Galishev VA, Russ. J. Org. Chem. 2004, 40, 1018-1026.

25 Pérez P, Domingo LR, Aurel MJ, Contreras R, Tetrahedron, 2003, 59, 3117-3125.

26 (a) Singh SP, Kumar D, Batra H, Naithani R, Rozas I, Elguero J, Can. J. Chem. 2000, 78, 1109-1120; (b) Fernández F, Caamaño O, García MD, Alkorta I, Elguero J, Tetrahedron, 2006, 62, 3362-3369; (c) Singh SP, Kumar V, Aggarwal R, Elguero J, J. Heterocycl. Chem., 2006, 43, 1003-1014.

27 Frisch MJ, Trucks GW, Schlegel HB, Scuseria GE, Robb MA, Cheeseman JR, Montgomery JA, Vreven JrT, Kudin KN, Burant JC, Millam JM, Iyengar SS, Tomasi J, Barone V, Mennucci B, Cossi M, Scalmani G, Rega N, Petersson GA, Nakatsuji H, Hada M, Ehara M, Toyota K, Fukuda R, Hasegawa J, Ishida M, Nakajima T, Honda Y, Kitao O, Nakai H, Klene M, Li X, Knox JE, Hratchian HP, Cross JB, Adamo C, 
Jaramillo J, Gomperts R, Stratmann RE, Yazyev O, Austin AJ, Cammi R, Pomelli C, Ochterski JW, Ayala PY, Morokuma K, Voth GA, Salvador P, Dannenberg JJ, Zakrzewski VG, Dapprich S, Daniels AD, Strain MC, Farkas O, Malick DK, Rabuck AD, Raghavachari K, Foresman JB, Ortiz JV, Cui Q, Baboul AG, Clifford S, Cioslowski J, Stefanov BB, Liu G, Liashenko A, Piskorz P, Komaromi I, Martin RL, Fox DJ, Keith T, Al-Laham MA, Peng CY, Nanayakkara A, Challacombe M, Gill PMW, Johnson B, Chen W, Wong MW, Gonzalez C, and Pople JA, Gaussian03, Revision C.02, Gaussian, Inc., Pittsburgh PA, 2003.

28 Beck AD, J. Chem. Phys., 1993, 98, 1372-1377.

29 Lee C, Yang W, and Parr RG, Phys. Rev. B37, 1988, 785-789; Becke AD, J. Chem.Phys., 1993, 98, 5648-5652; Nyden MR, Petersson GA, J. Chem. Phys., 1981, 75, 1843-1862; Foresman JB, Frish A, Exploring Chemistry with Electronic Structure Methods,Gaussian, Pittsburgh, 1996.

30 Here WJ, Radom L, Schleyer PvR, Pople, JA. Ab Initio Molecular Orbital Theory, New York, 1986.

31 Fukui K, J. Phys. Chem., 1970, 74, 4161-4163.

32 (a) Reed AE, Weinstock RB, Weinhold F. J. Chem. Phys. 1985; 83: 735-746; (b) Reed AE, Curtiss LA, Weinhold F. Chem. Rev. 1988; 88: 899-926.

33 Simkin BY, Sheikhet I, "Quantum Chemical and Statistical Theory of Solutions A Computational Approach" Ellis Horwood, London, 1995.

34 Cossi M, Barone V, Cammi R, Tomasi J, Chem. Phys. Lett. 1996, 255, 327-333; Cances MT, Mennunci V, Tomasi J, J. Chem. Phys. 1997, 107, 3032-3041; Barone V, Cossi M, Tomasi J, J. Comp. Chem. 1998, 19, 404-417.

35 COLLECT. Nonius BV, 1997-2000.

36 Otwinowski DSZ and Minor W, "Processing of X-ray Diffraction Data Collected in Oscillation Mode ", Methods in Enzymology : Macromolecular Crystallography, part A, 1997, 276, 307-326; Carter CWJr and Sweet RM, Eds., Academic Press.

37 SIR97. Altomare A, Burla MC, Camalli M, Cascarano GL, Giacovazzo C, Guagliardi A, Moliterni AGG, Polidori G, Spagna R J. Appl. Cryst. 1999, 32, 115-119.

38 HELX-97. Sheldrick GM, (1997). SHELX97. Programs for Crystal Structure nalysis (Release 97-2). University of Göttingen, Germany.

39 Nardelli M, Comput. Chem. 1983, 7, 95-97; Nardelli M, J. Appl. Crystallogr. 1995, 28, 659-662. 
40 Bruno MIJ, Cole JC, Edgington PR, Kessler MK, Macrae CF, McCabe P, Pearson J and Taylor R, Acta Crystallogr., B58, 2002, 389-397. 